\title{
Geoenvironmental Impact of Effluents Generated from Al Subiya Power Plant on the Northern Kuwait Bay, State of Kuwait
}

\author{
Mohamed Ibrahim El-Anbaawy ${ }^{1}$, Ahmed Abdelhalim ${ }^{1}$, Saeed Ndail ${ }^{1}$, Mohammad Al Sarawi ${ }^{2, *}$ \\ ${ }^{1}$ Department of Geology, College of science Cairo University, Cairo, Egypt \\ ${ }^{2}$ Department of Earth and Environmental Science, Kuwait University, Kuwait, State of Kuwait
}

Email address:

sarawi500@gmail.com (M. Al Sarawi)

*Corresponding author

\section{To cite this article:}

Mohamed Ibrahim El-Anbaawy, Ahmed Abdelhalim, Saeed Ndail, Mohammad Al Sarawi. Geoenvironmental Impact of Effluents Generated from Al Subiya Power Plant on the Northern Kuwait Bay, State of Kuwait. American Journal of Environmental Protection. Vol. 6, No. 5, 2017, pp. 120-139. doi: 10.11648/j.ajep.20170605.13

Received: July 2, 2017; Accepted: July 13, 2017; Published: October 11, 2017

\begin{abstract}
The present study proposed to assess the geo-environmental impacts of Al Subiya desalination plant discharges in the Arabian Gulf, Kuwait. Most of the power and freshwater needs in the Middle East are met by the desalination of seawater. With approximately 11 million $\mathrm{m}^{3}$ of freshwater being produced each day, the salinity of the seawater along the Gulf coast is increasing. Due to brine discharge into outlet, salinity combined with higher sea surface temperatures was increased is a big environmental challenge. Therefore, in the current study the evaluation of Salinity and conductivity was higher in outlet samples than the inlet. Understanding chemical quality of sediment is important since many pollutants bind strongly to sediment particles and are persistent in the aquatic environment. The chemical and physical make-up of sediment is largely a reflection of upstream and local geology, land use, surface run off and many other complex phenomena. Many persistent compounds have high molecular weight and therefore settle out quickly and are incorporated with other settled organic materials. Since the sediment-water layer is the most reactive layer of the sea bed, changes in the sediment distribution and its physio-chemical characteristics will certainly occur in relation to time and space. In view of this, a distribution map of the sediment is important to understand the changes in composition and nature of contamination in the aquatic environment. This study set out to survey Al Subiya desalination plant inlet and outlet of marine area in Kuwait's Arabian Gulf water and to generate an updated map of the sediments of Kuwait's marine environment, in terms of pollutant factors and the corresponding map of water quality parameters during the survey of one year. The specific objectives were: 1) total organic carbon (TOC), and total petroleum hydrocarbons(TPH) in the sediment collected from selected station, 2) analyze the water quality parameters ( $\mathrm{pH}$, Dissolved Oxygen, temperature, salinity, turbidity, conductivity potential) in Al Subiya desalination plant inlet and outlet region, and 3) examine the level of contamination in sediments in terms of size, composition and concentration of different metals and correlate this data with the available physical water quality parameters.
\end{abstract}

Keywords: Power Station, Brine, Trace Metals, Hydrodynamics, Contamination, Pollution, Bottom Sediment

\section{Introduction}

Kuwait depends heavily on desalination plants to provide its people with their sustainable needs for freshwater. Consequently, utilization of seawater through desalination is a major coastal activity in Kuwait. However, desalination plant including Al Subiya Plant, have several impacts of high temperature and salinity on the surrounding marine environment close to or near the plants outfall effluent discharge. It is expected that the discharged effluent contains residues of the treatment chemicals, as well as some corrosion material and by products [1]. The plants may also effect the environment indirectly, such as via the intensified use of energy by the plants [2].

Al Subiya power station is causing major threat to the marine Environment along the northern Kuwait bay. The out 
let is directly to the marine environment. The volatile liquid hydrocarbons (VLH's) and brines result from Al Subiya power station is threating northern Kuwait bay. The VLH's and brines are effecting the ecosystem, seawater and sediments in these area. However, Al Subiya power station is important in Kuwait to generated potable water and electricity (Figure 1). The power station work on heavy oil and their outlet is ending at the northern bay, which cause tremendous pollution to the seawater, and coastal and bottom sediments [3].

\subsection{Location}

The State of Kuwait is a country in Western Asia located at the north eastern corner of the Arabian Gulf. It has Strategic location at the head of the Arabian Gulf and it shares borders with Iraq and Saudi Arabia, Kuwait area is about $17,818 \mathrm{~km}^{2}$ and it lies between latitudes $28^{\circ} 30^{\prime}$ and 05 and longitude 4730 and $48036^{\prime}$ E (Figure 1). Several studies conducted on the contaminated soil near by the power plant and the oil lakes to identify the level of hydrocarbons and trace metals [4, 5, 6 and 7].

\subsection{Aim of the Study}

The main objectives of this study are:

1. To evaluate the level of pollution in Al Subiya coastal area.

2. To locate hot spots around Al Subiya power plant and construct an upgrade risk map.

3. To evaluate the level of VLH's and brines.

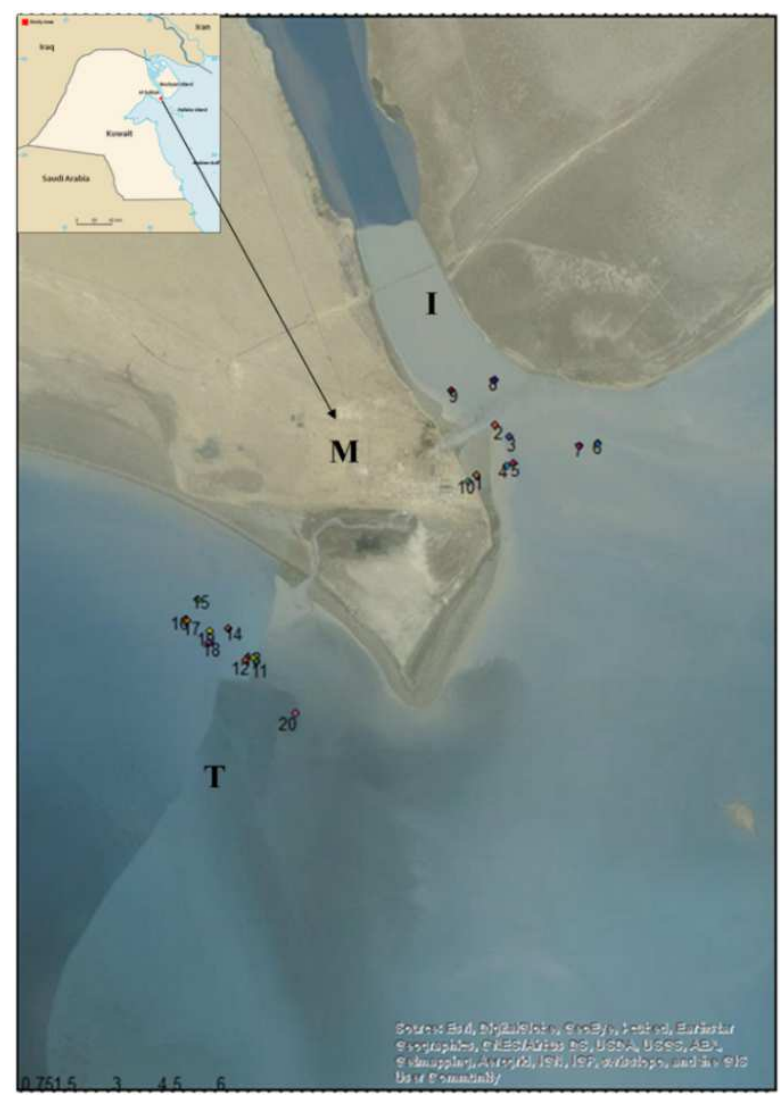

Figure 1. Location and sampling site.

\section{Materials and Methods}

\subsection{Geological Field Survey}

For the sake of site geological study of the coastal (inland) area around the location of Al Subiya plant, reconnaissance survey carried out through field trips. Several stops in the study area have been geologically investigated in terms of lithology of the rock units and sediment in the Ras Al Subiya peninsula (Figure 1). The lithological study includes the description of structural, textural and compositional characteristics of the sediments unit in the previous regional geological maps [8]. Based on such field survey the previous related maps of Kuwait, and interpretation of satellite images a site geological map was prepared in this study. During the field survey several representative photos have been taken and plotted on the map and satellite images.

\subsection{Collection of Samples}

For the environmental laboratory analysis, surface sea water samples and bottom sediment samples were collected from 22 stations, covering the inlet $\mathrm{N}$ (9 stations), nearshore M (10 stations), outlet T (3 stations) sites (Figure 1). These three sites have been denoted in the present study, by letters $\mathrm{N}, \mathrm{M}$ and $\mathrm{T}$ respectively as given in (Figure 1). The collected samples (water and sediments) were selected to represent each site related to the Al Subiya plant marginal marine area.

The $\mathrm{N}$ site represents the water inlet (intake) or water feeding location within the Khor Al Subiya (tidal creek). This location represents relatively shallow mainly inter tidal marine zone. Fresh water discharging from shut Al-Arab area minimizes the salinity of water feeding along the Khor $\mathrm{Al}$ Subiya tidal creek. The water and sediments samples were collected according to prior sampling plan, not only from the closest intake point, but also to represent further distances where an ambient seawater condition is predominant.

The $\mathrm{M}$ site represents the nearshore shallow open marine environmental zone receiving the outfalls that derived from the discharged effluents (mainly brine) after segregation in the immediate zone (i.e. outlet site, T). The water and sediment samples have been collected from different distances that measured from the initial outfall point, ranging from about 2000 to $4000 \mathrm{~m}$. This collection of samples was done according to sampling plan to examine the assumption that higher concentration closer to outfall point and lower concentration of the brine contents (environmental parameters) at further distance. The results of such examination with different controlling factors that affect the concentration distribution pattern of the study parameters. It is worth to mention that the $\mathrm{M}$ site is a part of northeastern zone of Kuwait bay. This zone is suggested to be characterized by stronger current circulation than in southern Kuwait territorial water. Water samples were collected during spring of 2016 by water sampler (Van Dorn). The bottom sediments were collected from the N, M and T using a van veen grab sampler operated from aboard a small boat. 


\subsection{Water Quality Field Measurements}

During collection of samples (Figure 1) the water quality filed measurements at the sites $\mathrm{N}, \mathrm{M}$ and $\mathrm{T}$ at the vicinity of Al Subiya plant coastal area. These measurements have been taken at the surface water layer (within one meter from sea surface).

\subsection{Laboratory Analysis}

The Laboratory investigation include three major groups of analysis namely; chemical, grain size and mineralogical analysis [9].

\section{Results}

The study of basic physical parameters such as $\mathrm{pH}$, Temperature, Conductivity, Salinity and Dissolved Oxygen are very important to know the nature of water quality. Therefore, in this study nine water samples from inlet (I), three water samples from outlet $(\mathrm{T})$ and ten from marine water $(\mathrm{M})$ samples were collected from Al Subiya power plant.

\subsection{Water Quality Parameters}

\subsection{1. $\mathrm{PH}$}

Kuwait Environmental Protection Agency [10] presents the default $\mathrm{pH}$ trigger of 8.2 for slightly disturbed tropically Kuwait ecosystems. Considering the small volume of waste brine planned for production at the Al Subiya power plant. The high degree of mixing and the buffering capacity of sea water $\mathrm{pH}$ will most likely rapidly revert to that of ambient sea water within meters of the brine outfall. From (Figures 1, 2 and 3) shows that there is slightly higher $\mathrm{pH}$ in outlet samples than the inlet and marine water samples near to Al Subiya power plant.

\subsubsection{Temperature}

Desalination process can increase the temperature of waste brine above the temperature of the ambient seawater. However, literature on temperature effects of desalination is often unclear about whether assessment of temperature ranges was based on model predictions or field measurements. From Table 1 represents that there is slightly higher temperature in outlet samples than the inlet and Marine water samples near to Al Subiya power plant.

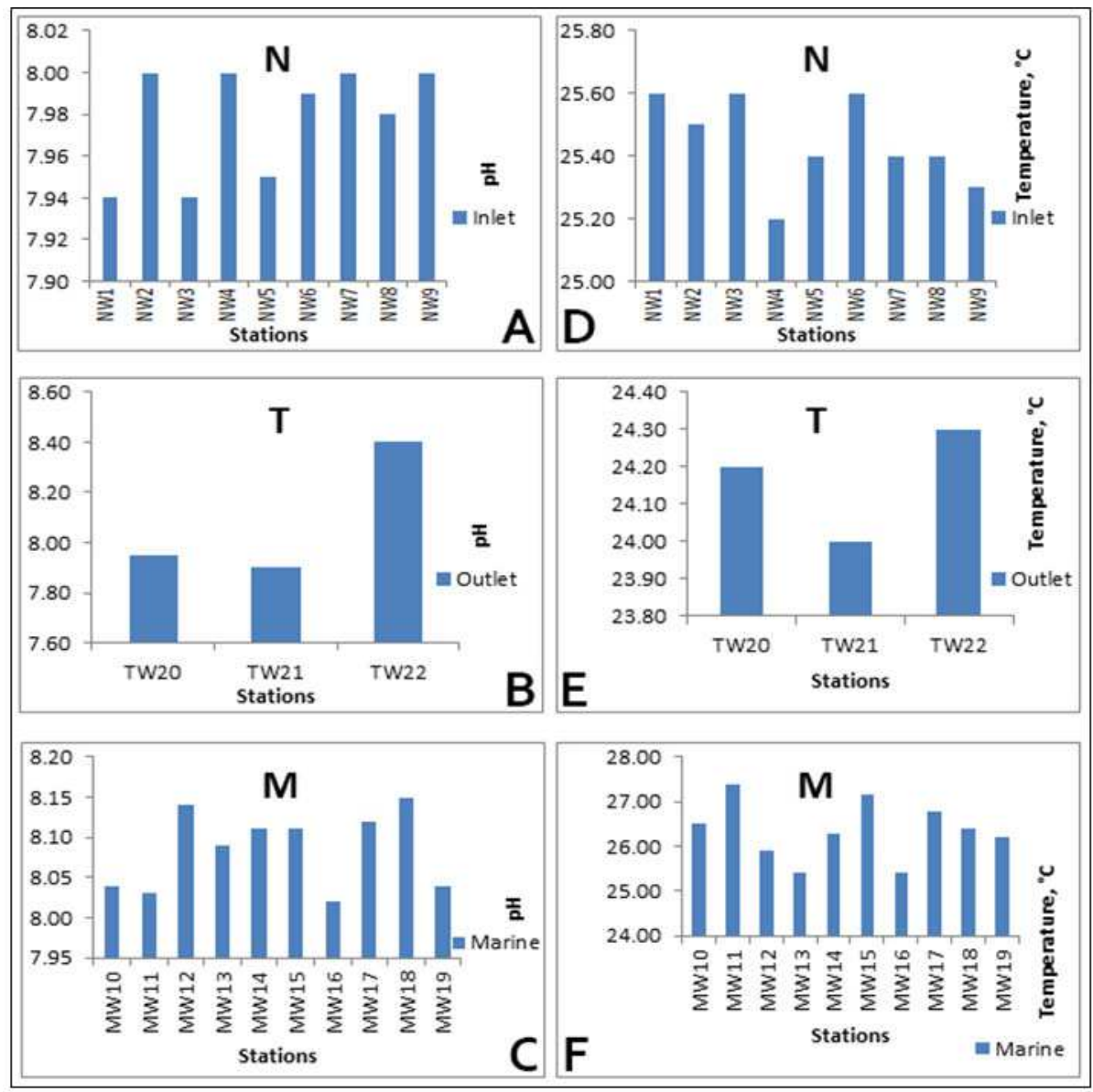

Figure 2. Distribution of Temperature and $p H$.

(A). $\mathrm{pH}$ measurements of water samples collected from inlet of Al Subiya power plant

(B). $\mathrm{pH}$ measurements of water samples collected from outlet of Al Subiya power plant

(C). $\mathrm{pH}$ measurements of water samples collected from Marine near to Al Subiya power plant

(D). Temperature measurements of water samples collected from inlet of Al Subiya power plant

(E). Temperature measurements of water samples collected from outlet of Al Subiya power plant

(F). Temperature measurements of water samples collected from Marine near to Al Subiya power plant 


\subsubsection{Conductivity}

Generally, conductivity of the sample increases with temperature as the mobility of the ions increases. In this study conductivity is higher in outlet samples than the inlet and Marine samples. Hence, it is well agreement with the above statement.

\subsubsection{Salinity}

The trend of salinity shows an increase since desalination activities started. An interesting fact that is clearly discernible shows that seasonal salinity variations were significant until 1996, since which time the seasonal variation has been limited to a much smaller range and is clearly incremental, although the corresponding seasonal temperature trend remained almost unchanged between 1993 and 2003.

There has been an upper salinity limit of $42 \mathrm{ppt}$ set by Kuwait Environmental Public Authority (KEPA) for Kuwait's marine waters. There has been a consistent breach of the upper salinity limit set forth by KEPA since 2002, except during November to February at few locations [11].

In this study states that Outlet water samples having higher salinity than the inlet and marine due to brine discharge (Figure 3).

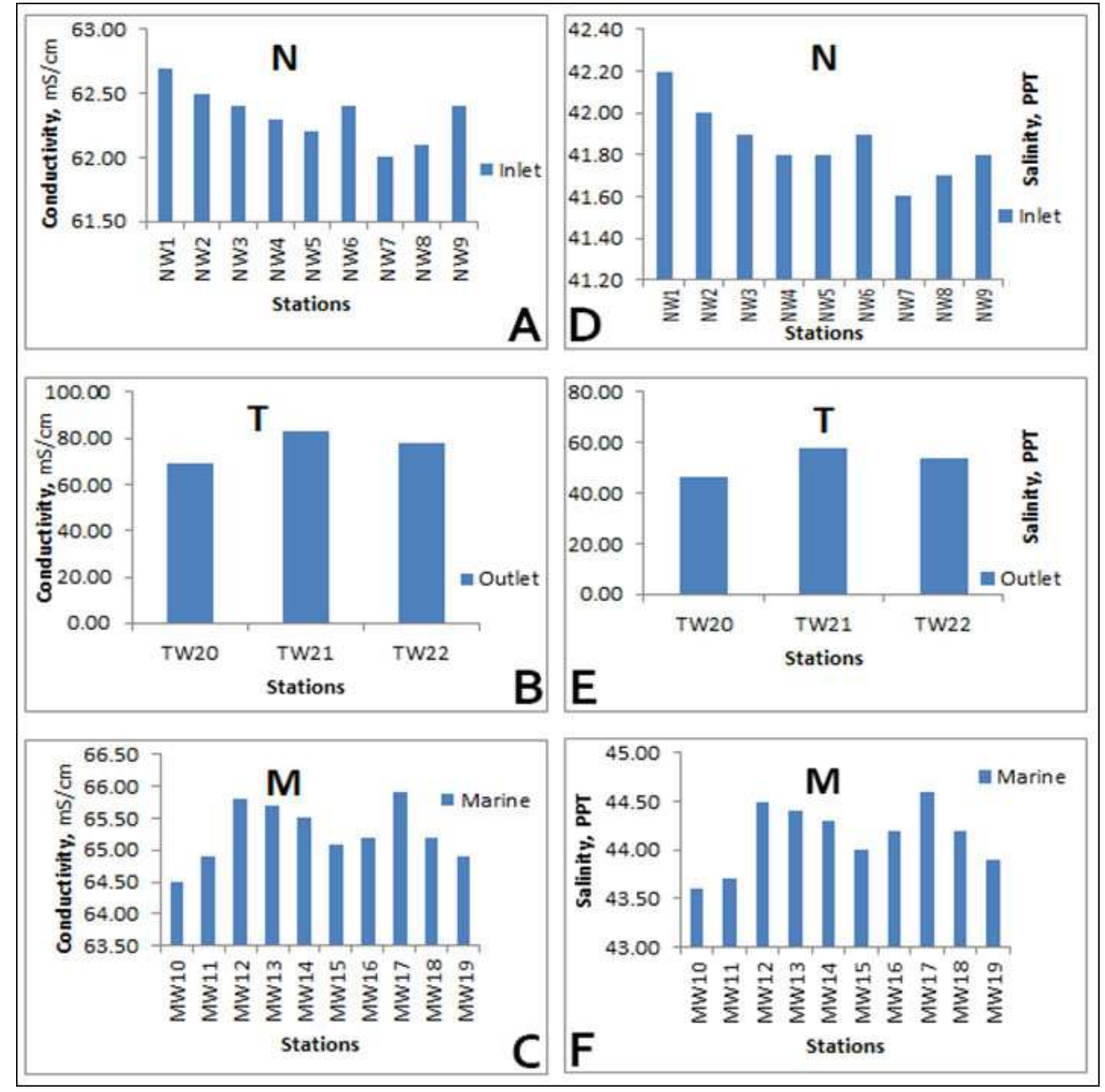

Figure 3. Distribution of Conductivity and Salinity.

(A). Conductivity measurement of water samples collected from inlet of Al Subiya power plant

(B). Conductivity measurements of water samples collected from outlet of Al Subiya power plant

(C). Conductivity measurements of water samples collected from Marine near to Al Subiya power plant

(D). Salinity measurements of water samples collected from inlet of Al Subiya power plant

(E). Salinity measurements of water samples collected from outlet of Al Subiya power plant

(F). Salinity measurements of water samples collected from Marine near to Al Subiya power plant

\subsubsection{Dissolved Oxygen}

Dissolved oxygen in water in the plant vicinity is affected by the effluent discharges from the plant. The concentration and saturation of oxygen will decrease due to the higher temperature and salinity of the effluents. The concentration of dissolved oxygen depends on the seawater temperature in the plant vicinity, concentration of oxygen in the discharge and the mixing of the discharge with the ambient. Dissolved oxygen results were obtainable in (Figure 4). 


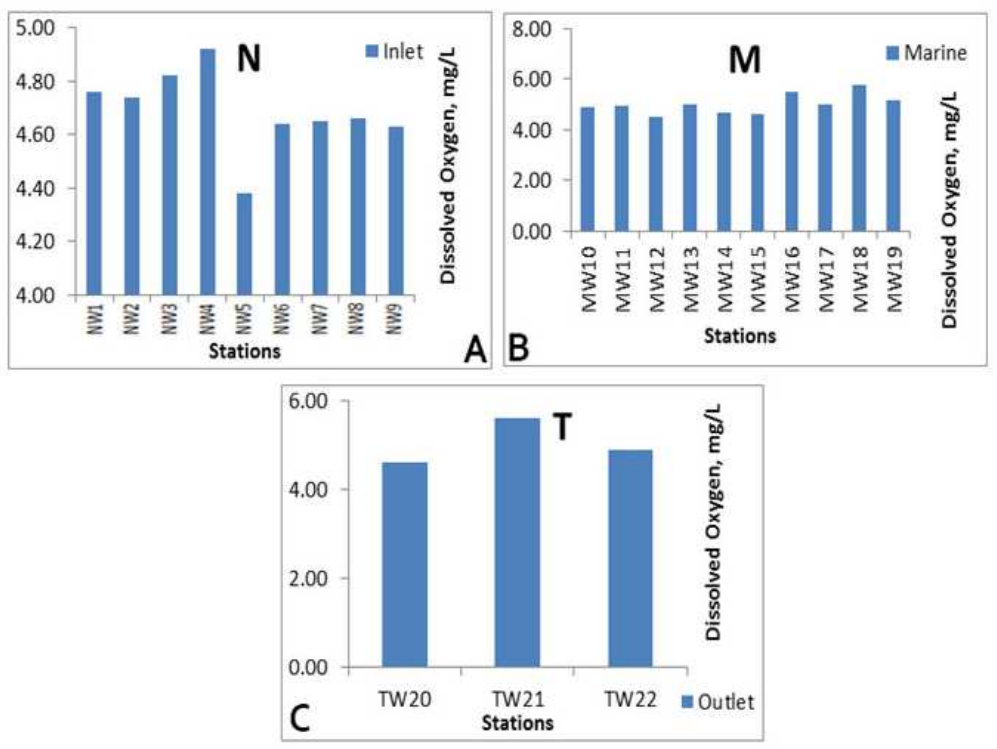

Figure 4. Distribution of Dissolved Oxygen.

(A). Dissolved oxygen of water samples collected from inlet of Al Subiya power plant

(B). Dissolved oxygen of water samples collected from outlet of Al Subiya power plant

(C). Dissolved oxygen of water samples collected from Marine near to Al Subiya power plant

\subsection{Sediment Quality Parameters}

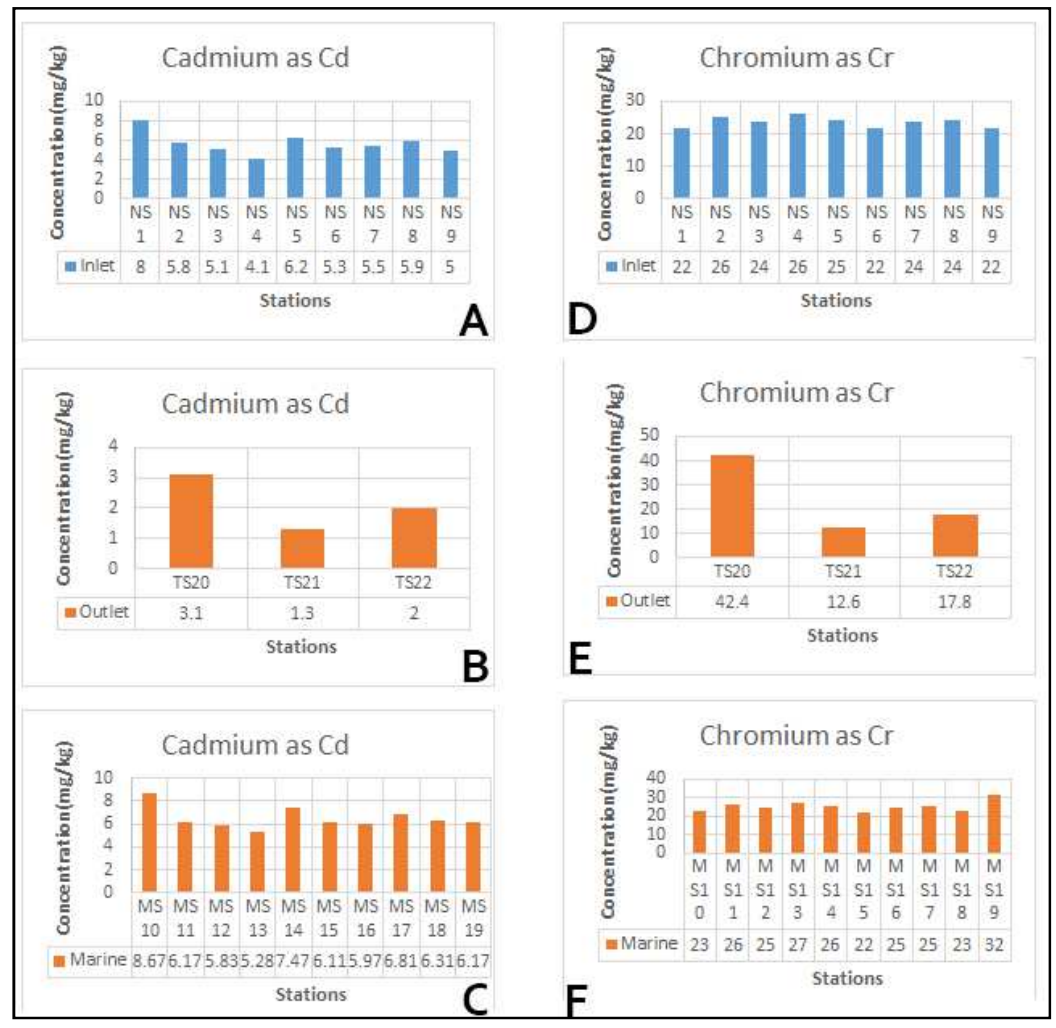

Figure 5. Distribution of Cadmium (Cd) and Chromium (Cr).

(A). Cadmium Concentration in Marine Sediment Samples Collected from inlet of the Al Subiya Power plant

(B). Cadmium Concentration in Marine Sediment Samples Collected from outlet of the Al Subiya Power plant

(C). Cadmium Concentration in Marine Sediment Samples Collected from Marine near to Al Subiya Power plant

(D). Chromium Concentration in Marine Sediment Samples Collected from inlet of the Al Subiya Power plant

(E). Chromium Concentration in Marine Sediment Samples Collected from outlet of the Al Subiya Power plant

(F). Chromium Concentration in Marine Sediment Samples Collected from Marine near to Al Subiya Power plant 


\subsubsection{Heavy Metals}

Sediment samples were prepared subjected to acid digestion for the determination of trace metals and analyzed by Atomic Absorption Spectrometry [11 and 12].

\subsubsection{Cadmium}

(Figure 5) illustrates that the concentration of Cadmium in sediment samples were found in all stations. Average cadmium concentration is $5.586 \mathrm{mg} / \mathrm{kg}$ of inlet samples and Average cadmium concentration is $6.479 \mathrm{mg} / \mathrm{kg}$ of Marine samples and Average cadmium concentration $2.1 \mathrm{mg} / \mathrm{kg}$ were found. Maximum concentration were found in Station 1 from inlet is $8.01 \mathrm{mg} / \mathrm{kg}$ and $8.67 \mathrm{mg} / \mathrm{kg}$ from station 10 of Marine and $3.1 \mathrm{mg} / \mathrm{kg}$ from outlet. Minimum were found in Station 4 from the inlet is $4.1 \mathrm{mg} / \mathrm{kg}, 5.28 \mathrm{mg} / \mathrm{kg}$ from station 13 of marine and $1.3 \mathrm{mg} / \mathrm{kg}$ from station 21 of outlet. From the figure explains that cadmium concentration were higher in Marine than inlet and outlet sediment samples.

\subsubsection{Chromium}

(Figure 5) demonstrates that the concentrations of Chromium in sediment samples were found in all stations.
Average chromium concentration is $23.33 \mathrm{mg} / \mathrm{kg}$ of inlet samples and Average cadmium concentration is $25.26 \mathrm{mg} / \mathrm{kg}$ of outlet samples were found. Maximum concentrations were found in Station 1 from inlet is $26.2 \mathrm{mg} / \mathrm{kg}$ and outlet is 31.5 $\mathrm{mg} / \mathrm{kg}$. Minimum were found in Station 4 from the inlet is $19.7 \mathrm{mg} / \mathrm{kg}$ and outlet is $22.3 \mathrm{mg} / \mathrm{kg}$. (Figure 5) describes that chromium concentration were found higher in outlet than inlet sediment samples.

\subsubsection{Cobalt}

(Figure 6) shows that the concentrations of Cobalt in sediment samples were found in all stations. Average cobalt concentration is $22.26 \mathrm{mg} / \mathrm{kg}$ of inlet samples and Average cadmium concentration is $24.1 \mathrm{mg} / \mathrm{kg}$ of outlet samples were found. Maximum concentration were found in Station 8 from inlet is $23.7 \mathrm{mg} / \mathrm{kg}$ and were found in Station 5 outlet is $25.9 \mathrm{mg} / \mathrm{kg}$. Minimum were found in Station 6 from the inlet is $20.8 \mathrm{mg} / \mathrm{kg}$ and were found in Station 3 from outlet is $22.1 \mathrm{mg} / \mathrm{kg}$. From the figure elucidates that cobalt concentration were found higher in outlet than inlet sediment samples.

\subsubsection{Copper}

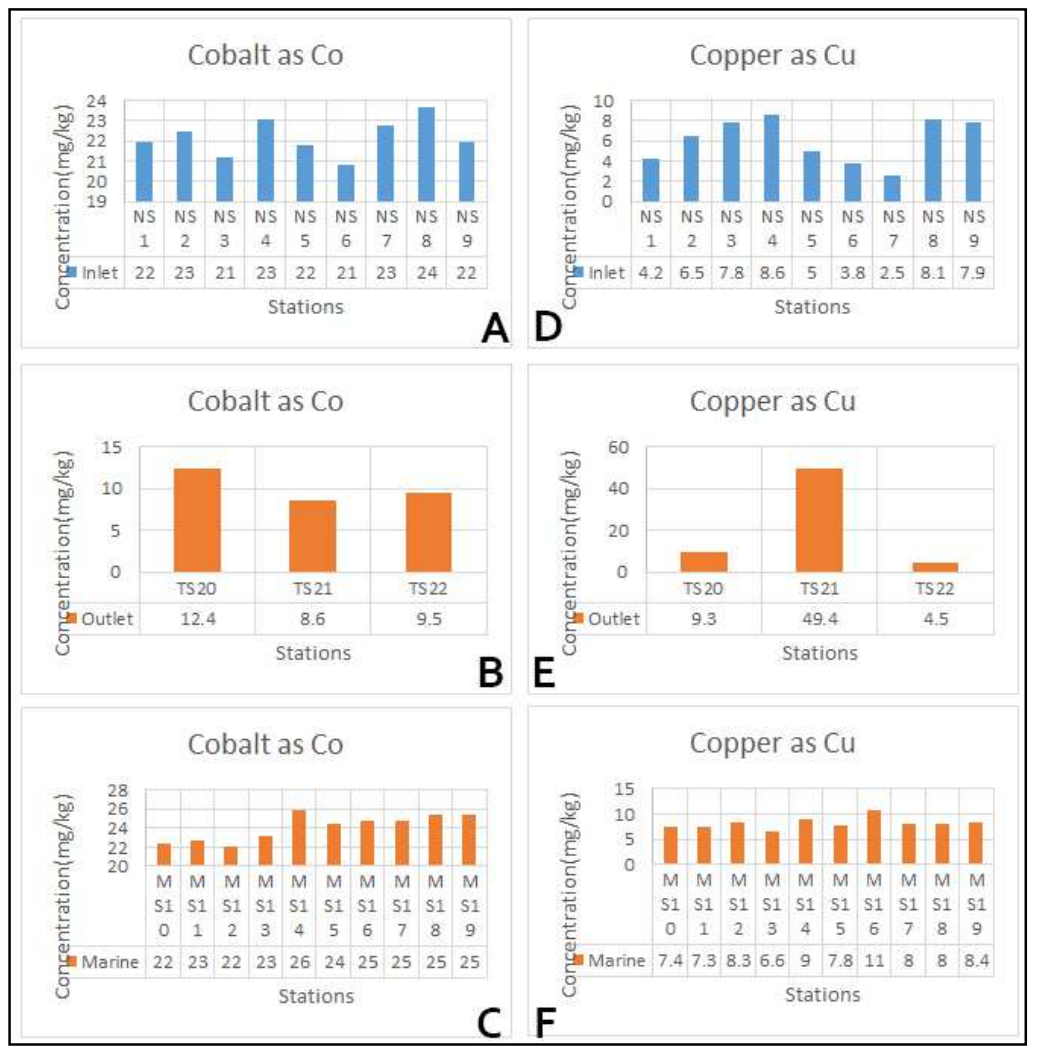

Figure 6. Distribution of Cobalt (Co) and Copper (Cu).

(A). Cobalt Concentration in Marin Sediment Samples Collected from inlet of the Al Subiya Power plant

(B). Cobalt Concentration in Marine Sediment Samples Collected from outlet of the Al Subiya Power plant

(C). Cobalt Concentration in Marine Sediment Samples Collected from Marine near to Al Subiya Power plant

(D). Copper Concentration in Marine Sediment Samples Collected from inlet of the Al Subiya Power plant

(E). Copper Concentration in Marine Sediment Samples Collected from outlet of the Al Subiya Power plant

(F). Copper Concentration in Marine Sediment Samples Collected from outlet of the Al Subiya Power plant 
(Figure 6) demonstrations that the concentrations of Copper in sediment samples were found in all stations. Average copper concentration is $6.266 \mathrm{mg} / \mathrm{kg}$ of inlet samples and Average cadmium concentration is $8.14 \mathrm{mg} / \mathrm{kg}$ of outlet samples were found. Maximum concentration were found in Station 8 from inlet is $8.59 \mathrm{mg} / \mathrm{kg}$ and were found in Station 7 outlet is $10.59 \mathrm{mg} / \mathrm{kg}$. Minimum were found in Station 7 from the inlet is $2.51 \mathrm{mg} / \mathrm{kg}$ and were found in Station 3 from outlet is $6.55 \mathrm{mg} / \mathrm{kg}$. From the figure elucidates that copper concentration were found higher in outlet from station 7 but lower in inlet from station 7 of the sediment samples.

\subsubsection{Iron}

(Figure 7) represent that the concentrations of Iron in sediment samples were found in all stations. Average Iron concentration is $6446.3 \mathrm{mg} / \mathrm{kg}$ of inlet samples and Average Iron concentration is $7800.5 \mathrm{mg} / \mathrm{kg}$ of outlet samples were found. Maximum concentration were found in Station 4 from inlet is $8762 \mathrm{mg} / \mathrm{kg}$ and were found in
Station 7 outlet is $8989 \mathrm{mg} / \mathrm{kg}$. Minimum were found in Station 1 from the inlet is $1733 \mathrm{mg} / \mathrm{kg}$ and were found in Station 4 from outlet is $6469 \mathrm{mg} / \mathrm{kg}$. From the figure elucidates that Iron concentration were found higher in outlet from station 7 but lower in inlet from station 4 of the sediment samples.

\subsubsection{Lithium}

(Figure 7) represent that the concentrations of Lithium in sediment samples were found in all stations. Average Lithium concentration is $8.633 \mathrm{mg} / \mathrm{kg}$ of inlet samples and Average Lithium concentration is $8.312 \mathrm{mg} / \mathrm{kg}$ of outlet samples were found. Maximum concentration were found in Station 3 from inlet is $9.52 \mathrm{mg} / \mathrm{kg}$ and were found in Station 10 outlet is $9.48 \mathrm{mg} / \mathrm{kg}$. Lithium were not detected in station 1 and minimum were found in Station 2 from the inlet is 7.38 $\mathrm{mg} / \mathrm{kg}$ and were found in Station 2 from outlet is $7.58 \mathrm{mg} / \mathrm{kg}$. From the figure elucidates that Lithium concentration were found higher in outlet from station 10 but lower in inlet from station 2 of the sediment samples.

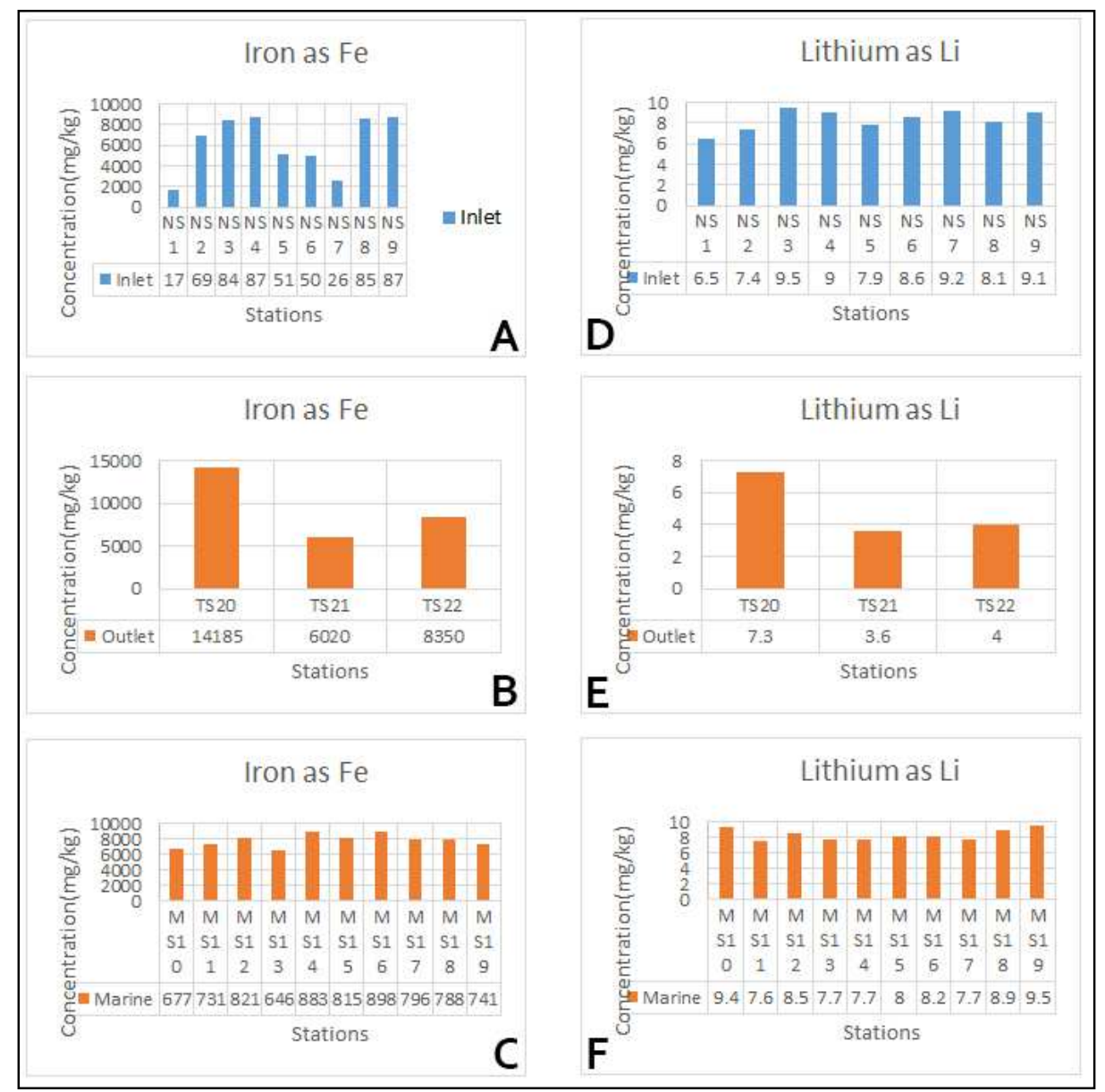

Figure 7. Distribution of Iron ( $\mathrm{Fe}$ ) and Lithium ( $\mathrm{Li}$ ).

(A). Iron Concentration in Marine Sediment Samples Collected from inlet of the Al Subiya Power plan

(B). Iron Concentration in Marine Sediment Samples Collected from outlet of the Al Subiya Power plant

(C). Iron Concentration in Marine Sediment Samples Collected from Marine near to Al Subiya Power plant

(D). Lithium Concentration in Marine Sediment Samples Collected from inlet of the Al Subiya Power plant

(E). Lithium Concentration in Marine Sediment Samples Collected from outlet of the Al Subiya Power plant

(F). Lithium Concentration in Marine Sediment Samples Collected from Marine near to the Al Subiya Power plant 


\subsubsection{Manganese}

(Figure 8) represent that the concentrations of Manganese in sediment samples were found in Inlet and outlet and Marine Sediments. Average Manganese concentration is $243.19 \mathrm{mg} / \mathrm{kg}$ of inlet samples, Average Manganese Concentration is $203.8 \mathrm{mg} / \mathrm{kg}$ of outlet samples and Average Manganese concentration is $318.37 \mathrm{mg} / \mathrm{kg}$ of Marine samples were found. Maximum concentration were found in Station NS4 from inlet is $332 \mathrm{mg} / \mathrm{kg}$, were found in Station MS10 from outlet is $307.1 \mathrm{mg} / \mathrm{kg}$ and were found in Station MS16 from Marine is $357 \mathrm{mg} / \mathrm{kg}$. Minimum were found in Station NS1 from the inlet is $61.9 \mathrm{mg} / \mathrm{kg}$, were found in Station TS21 is 129.4 and were found in Station MS14 from outlet is $235 \mathrm{mg} / \mathrm{kg}$. From the figures elucidates that Manganese concentration were found higher in Marine from station MS16 but lower in inlet from station NS1 of the sediment samples.

\subsubsection{Magnesium}

(Figure 8) represent that the concentrations of Magnesium in sediment samples were found in all stations. Average Magnesium concentration is $12676.8 \mathrm{mg} / \mathrm{kg}$ of inlet samples; Average Mg Concentration is $12988 \mathrm{mg} / \mathrm{kg}$ of outlet Samples and Average Magnesium concentration is $14540 \mathrm{mg} / \mathrm{kg}$ of Marine samples were found. Maximum concentration were found in Station NS4 from inlet is $15500 \mathrm{mg} / \mathrm{kg}$, were found in Station MS14 from Marine is $15700 \mathrm{mg} / \mathrm{kg}$ and were found in station TS20 outlet is $21635 \mathrm{mg} / \mathrm{kg}$. Minimum were found in Station NS1 from the inlet is $6468 \mathrm{mg} / \mathrm{kg}$, were found in Station MS14 from outlet is $12800 \mathrm{mg} / \mathrm{kg}$ and were found in station TS21 is $7510 \mathrm{mg} / \mathrm{kg}$. From the figure elucidates that Magnesium concentration were found higher in outlet from station TS20 but lower in inlet from station NS1 of the sediment samples.

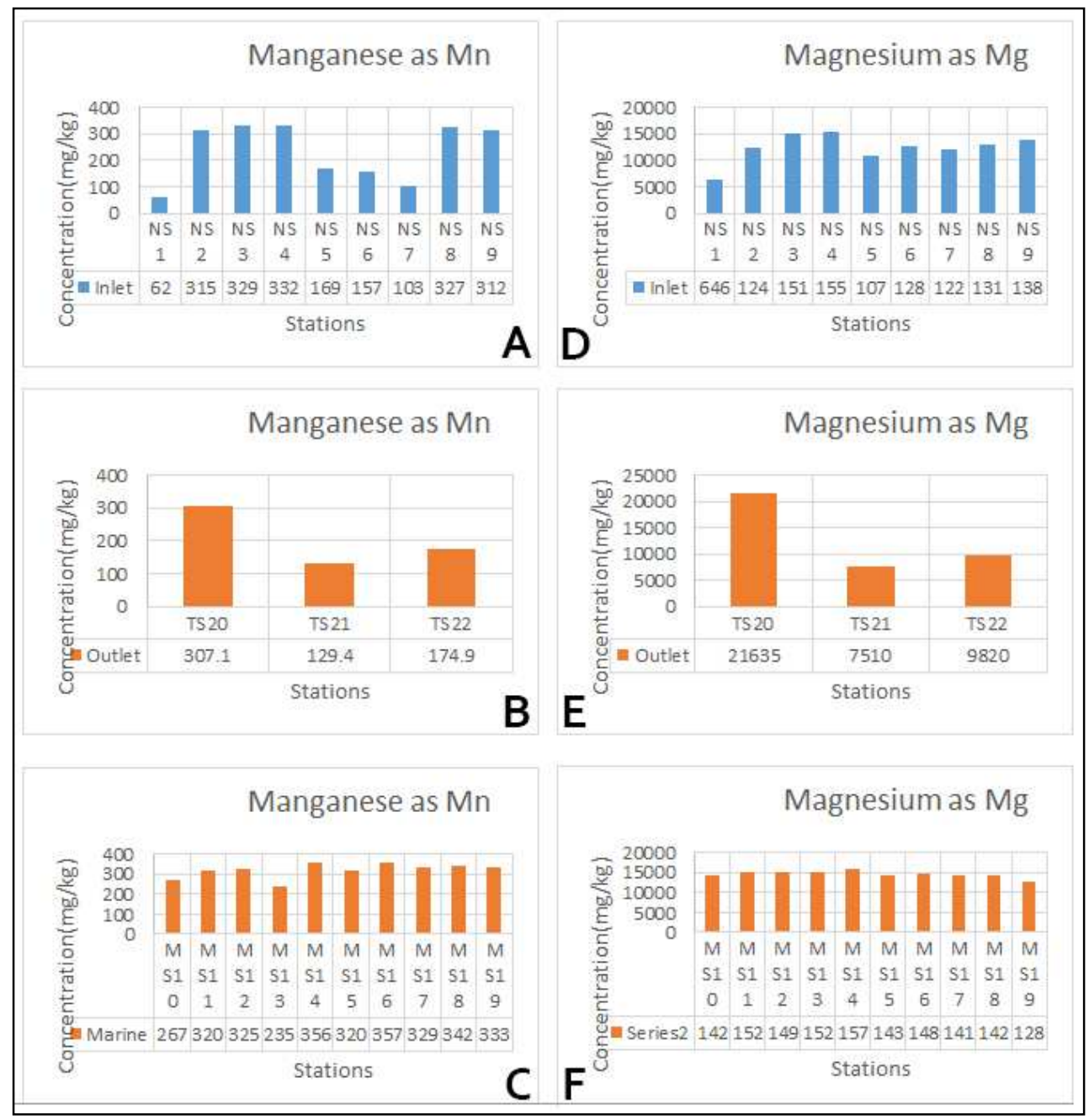

Figure 8. Distribution of Manganese (Mn) nd Magnisium (Mg).

(A). Manganese Concentration in Marine Sediment Samples Collected from inlet of the Al Subiya Power plant

(B). Manganese Concentration in Marine Sediment Samples Collected from outlet of the Al Subiya Power plant

(C). Manganese Concentration in Marine Sediment Samples Collected from Marine near to the Al Subiya Power plant

(D). Magnesium Concentration in Marine Sediment Samples Collected from inlet of the Al Subiya Power plant

(E). Magnesium Concentration in Marine Sediment Samples Collected from outlet of the A1 Subiya Power plant

(F). Magnesium Concentration in Marine Sediment Samples Collected from Marine near to Al Subiya Power plant 


\subsubsection{Nickel}

(Figure 9) represent that the concentrations of Nickel in sediment samples were found in all stations. Average Nickel concentration is $69.56 \mathrm{mg} / \mathrm{kg}$ in inlet samples, Average of Nickel Concentration is 49.67 in Outlet samples and Average Nickel concentration is $85.49 \mathrm{mg} / \mathrm{kg}$ in Marine samples were found. Maximum concentration were found in Station NS8 from inlet is $91.6 \mathrm{mg} / \mathrm{kg}$, were found in Station TS20 from outlet is 77.8 and were found in Station MS16 from Marine is $97.3 \mathrm{mg} / \mathrm{kg}$. Minimum were found in Station NS7 from the inlet is $26 \mathrm{mg} / \mathrm{kg}$, Were found in station TS21 from outlet is 27.2 and were found in Station MS13 from Marine is $63.2 \mathrm{mg} / \mathrm{kg}$. From the figure elucidates that Nickel concentration were found higher in Marine from station MS16 but lower in inlet from station NS7 of the sediment samples.

\subsubsection{Vanadium}

(Figure 9) represent that the concentrations of Vanadium in sediment samples were found in all stations. Average Vanadium concentration is $18.874 \mathrm{mg} / \mathrm{kg}$ of inlet samples, Average Vanadium concentration is $61.43 \mathrm{mg} / \mathrm{kg}$ of outlet samples and Average Vanadium concentration is $17.86 \mathrm{mg} / \mathrm{kg}$ of Marine samples were found. Maximum concentration were found in Station NS3 from inlet is $21.6 \mathrm{mg} / \mathrm{kg}$, were found in Station TS23 from outlet is $64.3 \mathrm{mg} / \mathrm{kg}$ and were found in Station MS10 from Marine is $21.3 \mathrm{mg} / \mathrm{kg}$. Minimum were found in Station NS5 from the inlet is $17.96 \mathrm{mg} / \mathrm{kg}$, were found in Station TS21 from the outlet is $56.5 \mathrm{mg} / \mathrm{kg}$ and were found in Station MS19 from Marine is $8.4 \mathrm{mg} / \mathrm{kg}$. From the figure elucidates that Vanadium concentration were found higher in outlet from station TS22 but lower in inlet from station NS5 of the sediment samples.

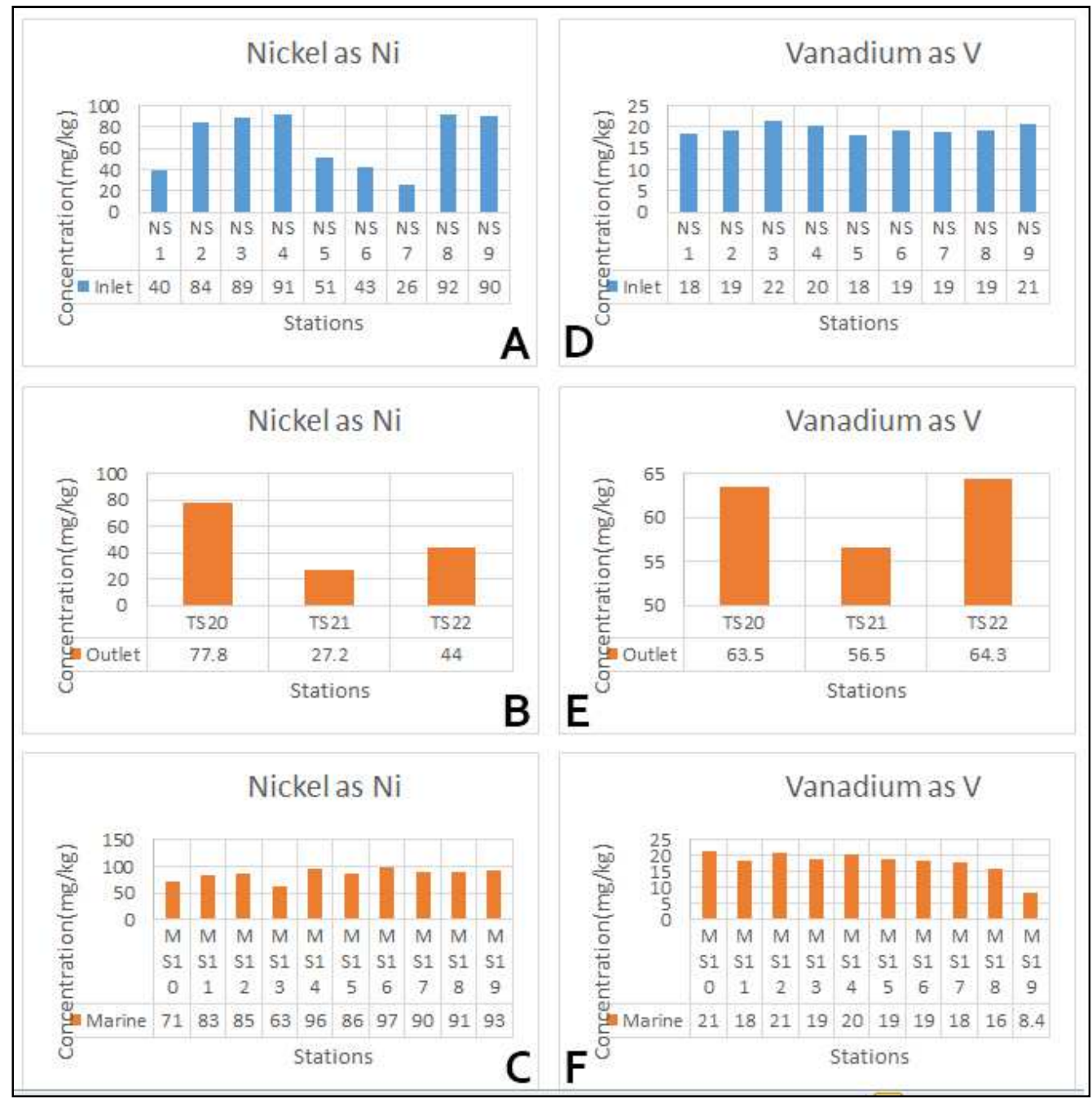

Figure 9. Distribution of Nickel (Ni) and Vanadium (V).

(A). Nickel Concentration in Marine Sediment Samples Collected from inlet of the Al Subiya Power plant

(B). Nickel Concentration in Marine Sediment Samples Collected from outlet of the Al Subiya Power plant

(C). Nickel Concentration in Marine Sediment Samples Collected from Marine near to Al Subiya Power plant

(D). Vanadium Concentration in Marine Sediment Samples Collected from inlet of the Al Subiya Power plant

(E). Vanadium Concentration in Marine Sediment Samples Collected from outlet of the Al Subiya Power plant

(F). Vanadium Concentration in Marine Sediment Samples Collected from Marine near to Al Subiya Power plant 


\subsubsection{Zinc}

(Figure 10) represent that the concentrations of $\mathrm{Zn}$ in sediment samples were found in all stations. Average $\mathrm{Zn}$ concentration is $9.11 \mathrm{mg} / \mathrm{kg}$ of inlet samples, Average $\mathrm{Zn}$ concentration is $48.63 \mathrm{mg} / \mathrm{kg}$ of outlet samples and Average $\mathrm{Zn}$ concentration is $19.17 \mathrm{mg} / \mathrm{kg}$ of Marine samples were found. Maximum concentration was found in Station NS4 from inlet is $22.47 \mathrm{mg} / \mathrm{kg}$, were found in Station TS21 from Marine is $80.6 \mathrm{mg} / \mathrm{kg}$ and were found in Station MS16 from Marine is $27.8 \mathrm{mg} / \mathrm{kg}$. Minimum were found in Station NS5 from the inlet is $6.88 \mathrm{mg} / \mathrm{kg}$, were found in Station TS22 from outlet is $23.7 \mathrm{mg} / \mathrm{kg}$ and were found in Station MS13 from Marine is $8.6 \mathrm{mg} / \mathrm{kg}$. From the figure elucidates that zinc concentration were not found in inlet samples of stations 1,6 and 7. Higher concentrations were found in outlet from station TS22 but lower concentrations were found in inlet samples $6.88 \mathrm{mg} / \mathrm{kg}$ from station NS5 of the sediment samples.

\subsubsection{As}

(Figure 10) represent that the concentration of As in outlet sediment samples were found in all stations. But in Inlet and Marine sediment samples as were not found. Average As concentration is $3.01 \mathrm{mg} / \mathrm{kg}$ of outlet samples were found. Maximum concentration were found in Station TS21 from outlet is $4.48 \mathrm{mg} / \mathrm{kg}$ and minimum were found in Station TS22 is $2.15 \mathrm{mg} / \mathrm{kg}$.

$\mathrm{Mo}, \mathrm{Se}, \mathrm{U}$ and $\mathrm{Hg}$ were not found in Marine surface sediment samples collected from ten inlet and ten outlet samples near Al-Subiya power plant.

\subsection{Sediment Parameters}

From both (Tables 1 and 2) it's clear that TOC and brines are higher at the marine sediments were the discharge is taking its way to the coastal environment.

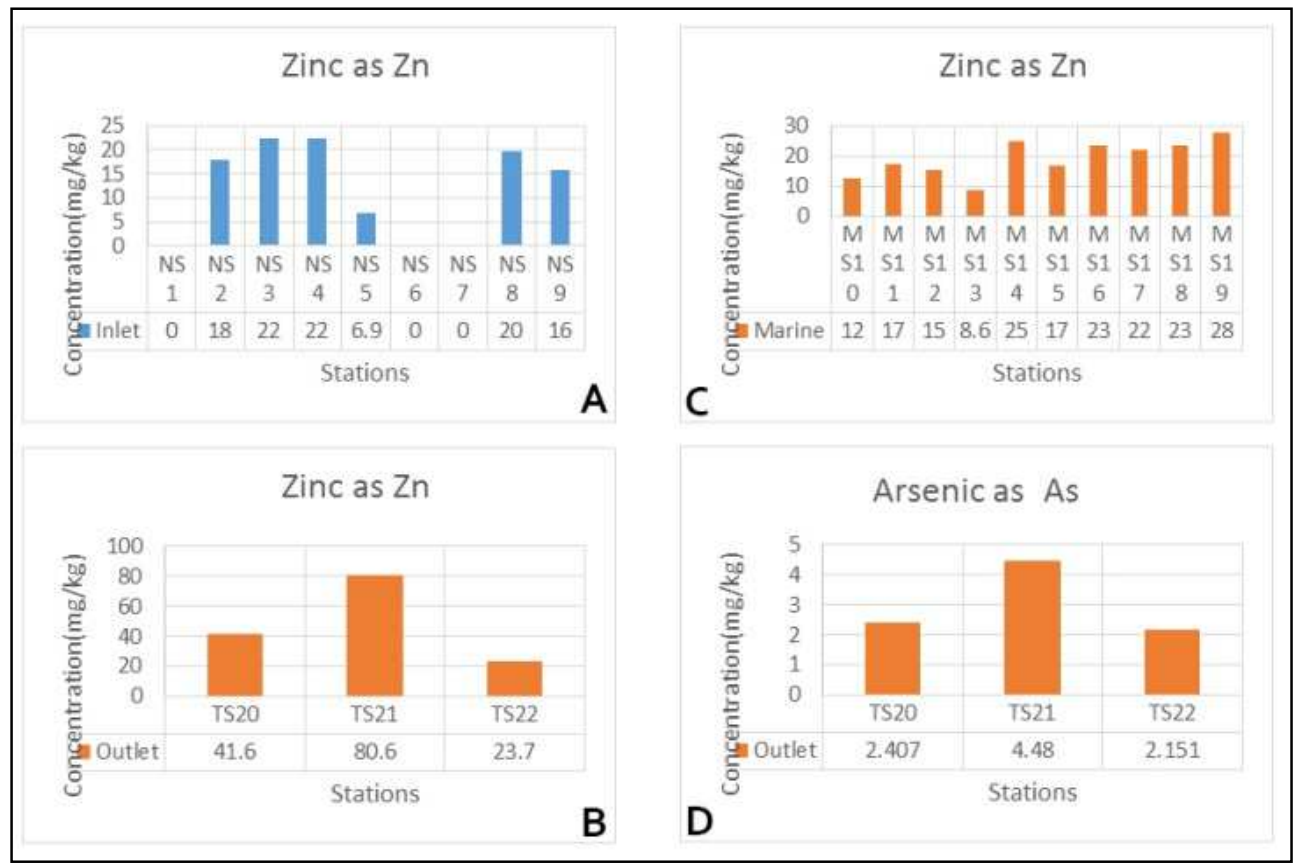

Figure 10. Distribution of Zinc (Zn) and Arsenic (As).

(A). Zinc Concentration in Marine Sediment Samples Collected from inlet of the Al Subiya Power plant

(B). Zinc Concentration in Marine Sediment Samples Collected from outlet of the Al Subiya Power plant

(C). Zinc Concentration in Marine Sediment Samples Collected from Marine near to the Al Subiya Power plant

(D). As Concentration in Marine Sediment Samples Collected from outlet of the Al Subiya Power plant

Table 1. Distribution of Sediment parameters of the near shore Samples in Al Subiya marine area.

\begin{tabular}{|c|c|c|c|c|c|c|c|c|c|c|c|c|}
\hline Parameter & Method & Units & MS10 & MS11 & MS12 & MS13 & MS14 & MS15 & MS16 & MS17 & MS18 & MS19 \\
\hline Total Organic Carbon (TOC) & EPA 9060 & $\mathrm{mg} / \mathrm{kg}$ & 0.087 & 0.079 & 0.088 & 0.096 & 0.154 & 0.172 & 0.08 & 0.076 & 0.113 & 0.092 \\
\hline Brines (Sodium Chloride) & - & $\mathrm{mg} / \mathrm{kg}$ & 21215 & 18321 & 17347 & 25297 & 19898 & 18817 & 25409 & 21808 & 30247 & 24117 \\
\hline Total Petroleum Hydrocarbons(TPH) & EPA $9071 \mathrm{~B}$ & $\mathrm{mg} / \mathrm{kg}$ & $<5$ & $<5$ & $<5$ & $<5$ & $<5$ & $<5$ & $<5$ & $<5$ & $<5$ & $<5$ \\
\hline
\end{tabular}

Table 2. Distribution of Sediment parameters of the Outlet Samples (T) in Al Subiya marine area.

\begin{tabular}{|c|c|c|c|c|c|}
\hline Parameter & Method & Units & TS20 & TS21 & TS22 \\
\hline Total Organic Carbon (TOC) & EPA 9060 & $\mathrm{mg} / \mathrm{kg}$ & 0.052 & 0.162 & 0.028 \\
\hline Brines (Sodium Chloride) & - & $\mathrm{mg} / \mathrm{kg}$ & 21111 & 16787 & 33065 \\
\hline Total Petroleum Hydrocarbons(TPH) & EPA $9071 \mathrm{~B}$ & $\mathrm{mg} / \mathrm{kg}$ & $<5$ & $<5$ & $<5$ \\
\hline
\end{tabular}




\section{Discussions}

\subsection{Marine Hydro Geological Setting}

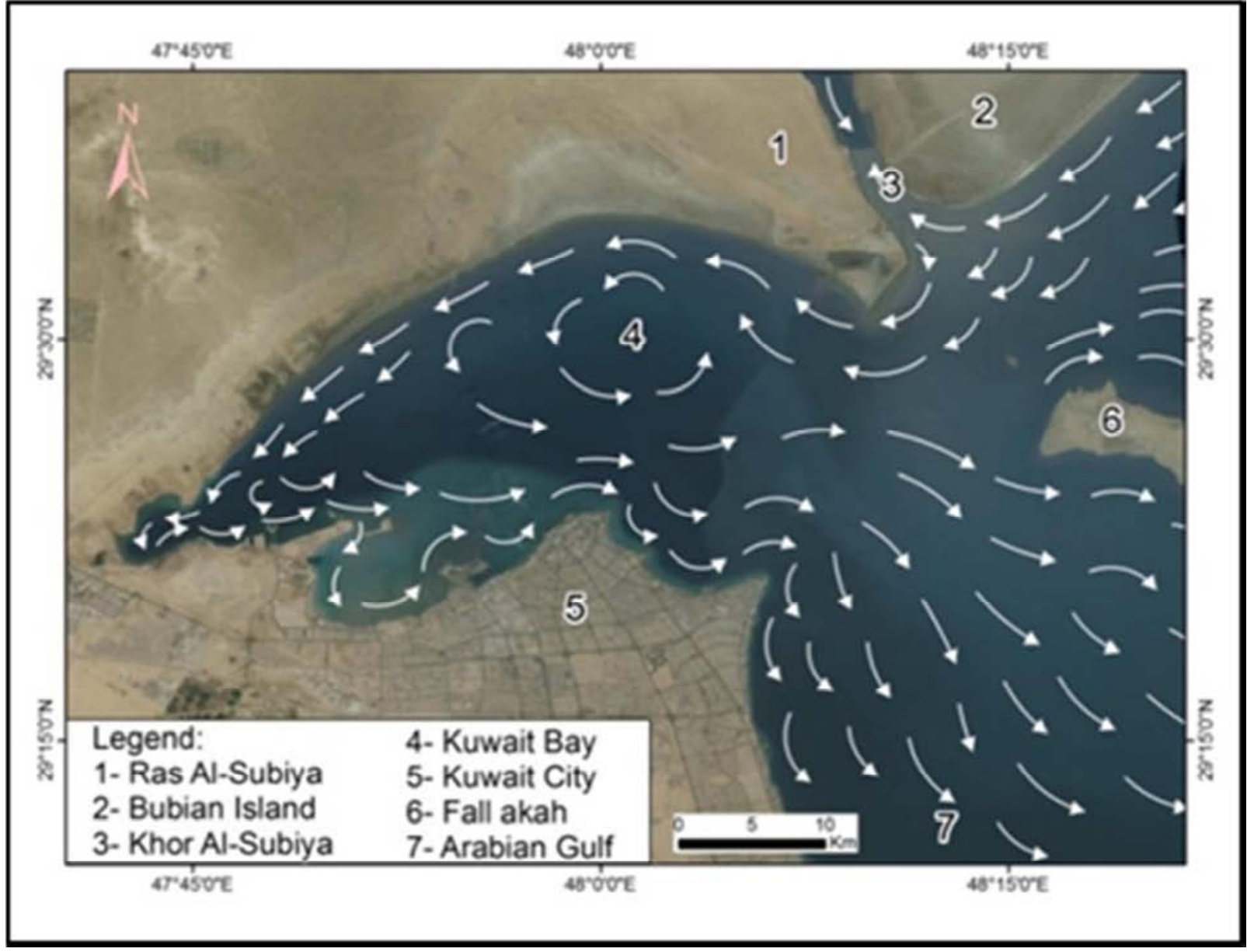

Figure 11. Anti-Clock Wise of Current Movement from North to South.

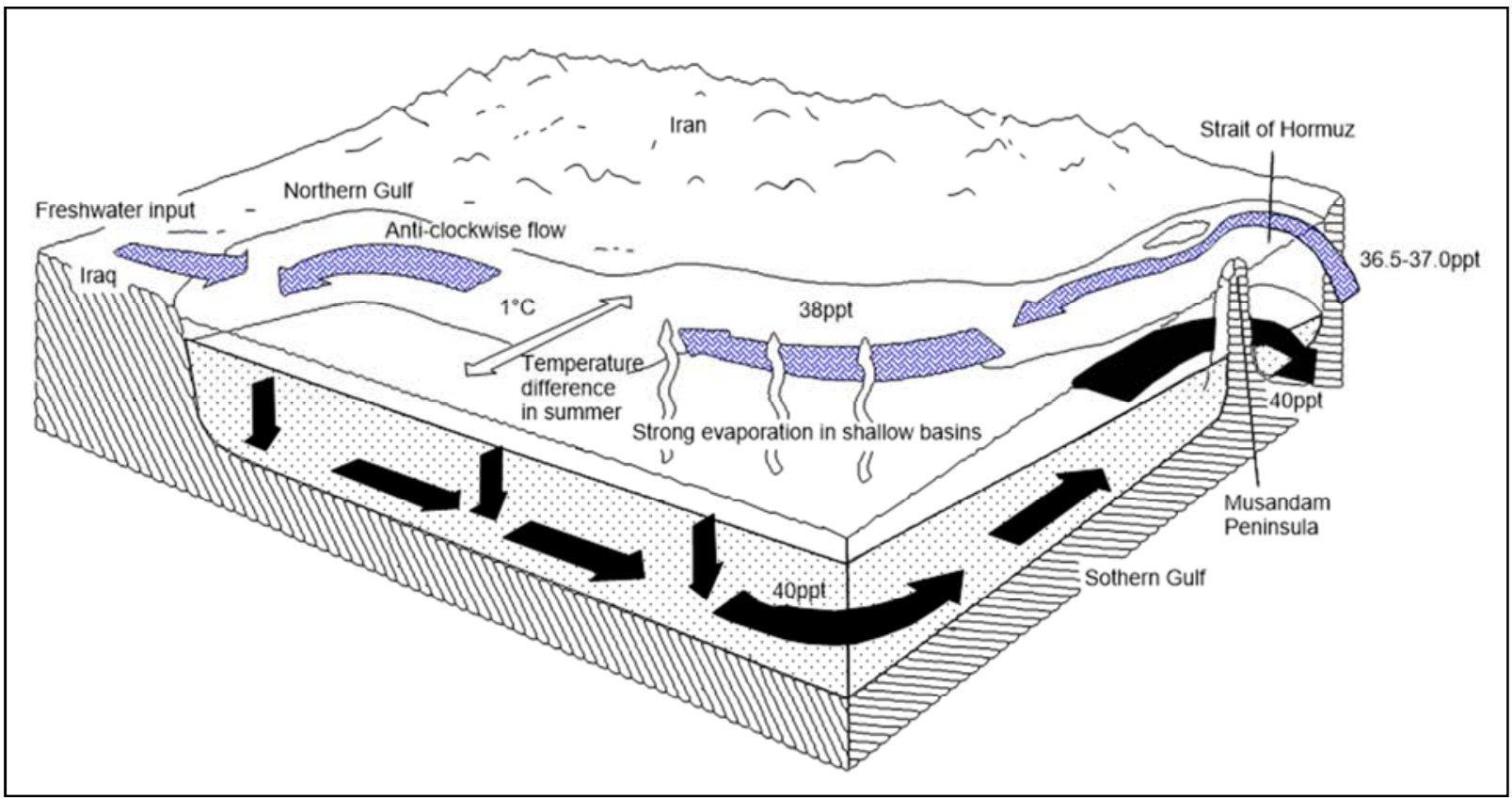

Figure 12. Current Circulation within the Arabian Gulf. 
To understand the potential effects of discharge outlet area of Al Subiya plant on the surrounding marginal marine environment, it is preferable to discuss the hydro geological setting or oceanographic characteristics included the study area, as a northern part of Arabian Gulf. The Kuwait bay is characterized by interplay of regional and local marine and terrestrial influences in addition to biological interference key oceanographic characteristics of the marine hydro geological setting include water exchange, bathymetry, wave currents and bottom currents and stretches of tidal cycles. The terrestrial contribution is mainly represented by erosional beach sands, downstream sediments and biogenic products. However, the climatic and astronomic conditions, (e.g. temperature, evaporation, winds and astronomical tides) are quite efficient in this environmental system all these regional and local hydro dynamic factors seem to be potentially affected the Al Subiya marginal marine sediments and water distribution.

The sediments of Al Subiya area are included in large tide - dominated estuarine marginal marine depositional system. In this system the wave currents are normally subordinate of secondary importance except in periods of dust storms where additional wave flushing and fallout dust are generated by wind.

It is evident by many authors that the current (mainly tidal current) circulation in the northern part of Kuwait bay including the Al Subiya study area (Figure 12), is generally quite efficient in transportation of the fine (mainly silt mud) sediments. The tidal current, from west to east, carry's a large part of the organic matter and other potential pollutants in suspension out to the open Arabian Gulf through the major current flows (Figure 13). Therefore, tides are controlling sediments distributions, morphodynamics and geomorphic features of the study area.

The difference in tidal level (6-4 meters) is very large in the study area where amount of sea water flushing into the intertidal flats with $10-15 \mathrm{~cm} / \mathrm{sec}$. velocity, create a massive change in the ecosystem in a daily interval the area along the tidal flat is highly bioturbated with macro and microorganisms.

\subsection{Environmental Profile and Controlling Factors}

Generally, most of the impact on the marine environment is a consequence of the positioning of the feed (inlet) and discharge (outlet) points. The severity of the impact is a function of the level of natural sensitivity and hydro geological factors. Other factors such as technological and compositional factors dilution of the brine and therefore the spatial range of the impact
The bathymetric condition of Kuwait bay is likely to affect the recirculation characteristics. In the study area the sediments dissipation depends largely on the bathymetry of the tidal flat site as well as on the other hydrodynamic parameters (e.g. wind intensities, waves and current). For instance, if the sea is shallow the fine sediments up wells to surface due to elevated temperature and spreads over depending on currents and wind. The shallowness (2-5m) along the coastal areas, including tidal flats outfall area on the capacity of outfall area on the Kuwait bay coast, commonly restricts the capacity of outfall area from allowing rapid mixing and dilution.

Consequently, the hydrogeological setting along the northern part of Kuwait bay including current circulation condition, tidal pattern and bathymetric features, influences the water transportation and dispersion of the fine sediments within Al Subiya marginal marine area in which the efficient discharged hydrologically, this outfall area is similar to northeastern part of Kuwait bay, represents relative shallow semi - enclosed depositional environment with local circulation and exchange of water with the open seq. However, the fine muddy sediments which may be associated with any effluents or suspended materials in force to move by prevailing current toward west (Figure 11) on the other side, Khur Al Subiya tidal creek channel (3-4 m depth in which the water inlet is located, is influenced by stream flow and tidal current forces.

\subsection{Composition of Bottom Sediments}

From the foregoing results it appears that textural and composition of the study bottom sediments and distribution have been influenced by their distribution have been influenced by their distribution have been influenced by their hydro geological setting and sources. The textural characteristics of the study sediments and their mineralogical and chemical composition are discussed in the present section as one of major factors controlling the environmental impacts of the effluents discharged from Al Subiya plant. Four representative samples (NS 6, Ms11, and TS 20 and 22) have been selected to represents respectively, around the plant of Al Subiya. Bulk mineralogical and chemical composition of these samples is determined as shown in (Figures 11 and 12), while their tray mineral distribution (Figures $13 \& 14$ ).

The bulk mineralogical analysis by XRD technique (Figures 10 and 11) indicates that quartz (29-43\%) are also represented as given in (Table 6). feldspars (7-18\%) are represented by albite and microcline. the maximum content of feldspars is recorded in sample TS 20 (Table 6). 

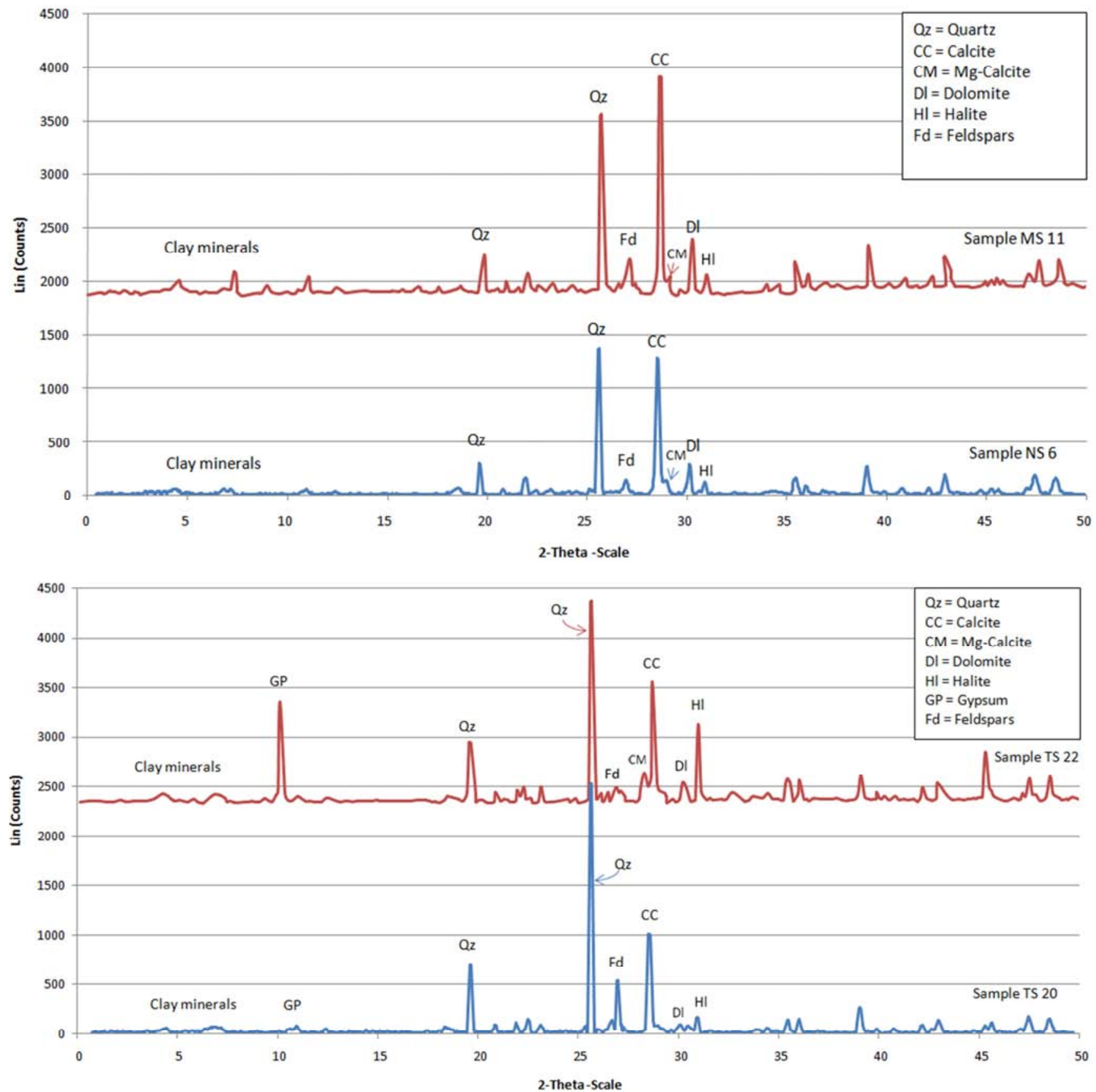

Figure 13. Bulk mineralogical analysis.

Practically the clay minerals are present in considerable amount in the silt-mud samples; however, they are recorded in trace amounts in bulk mineralogical analysis (Table 3), which may be due to their poorly crystalline structure. So, such difficulty of clay minerals identification needs separation of clay size fractions and their preparation of clay size fractions and their preparation as preferred oriented particles as well as their treatments by glycolation and heating. In spite of this difficulties some clay minerals could be detected e.g. Kaolinite, illite and chlorite in bulk samples that collected from some bottom sediments of Kuwait Bay (13).

Table 3. Mineral composition of representative sediment samples in Al Subiya marginal marine area as revealed from bulk mineralogy by XRD (The number\% means reactive abundance).

\begin{tabular}{|c|c|c|c|c|c|c|c|c|}
\hline Samples No. & Quartz & Calcite & Mg-Calcite & Dolomite & Halite & Gypsum & Feldspars & Clay Minerals \\
\hline NS 6 & 38 & 36 & 4 & 10 & 3 & - & 7 & Traces \\
\hline MS 11 & 29 & 35 & 3 & 12 & 4 & - & 10 & Traces \\
\hline TS 20 & 43 & 22 & $=$ & 3 & 10 & 3 & 18 & Traces \\
\hline TS 22 & 31 & 21 & 4 & 4 & 9 & 22 & 9 & Traces \\
\hline
\end{tabular}




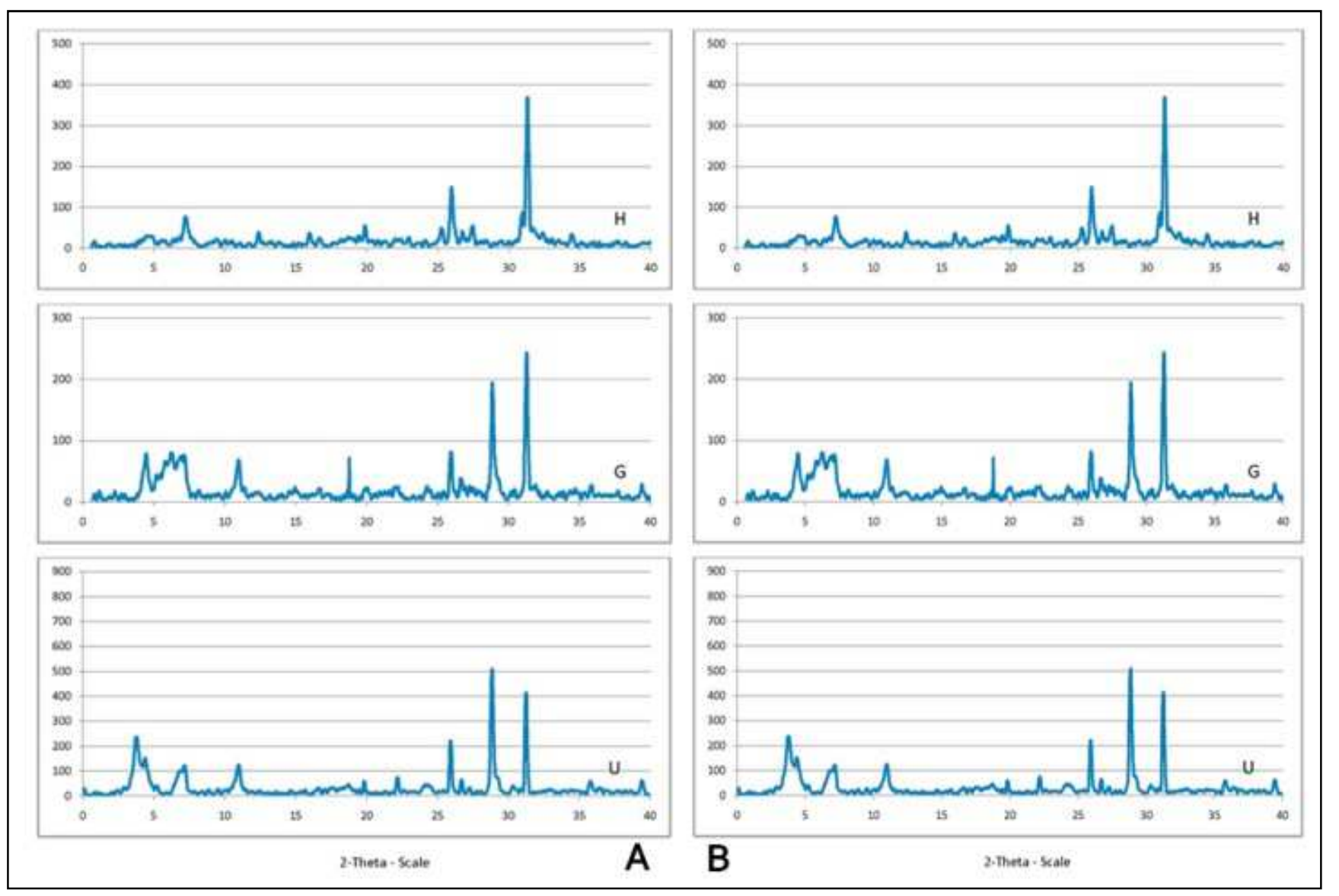

Figure 14. Chemical composition.

Mainly kaolinite, chlorite, illite and mixed layer as interpreted from clay mineralogical analysis of clay fractions (See Table 3).

Based on the distribution of the relative abundance of the carbonate and evaporate minerals, the study sediments could be categorized into two types; samples of $\mathrm{N}$ and $\mathrm{M}$ sites in one side (the first type) as they are compositionally similar to each other, and the samples of the outlet site in another side (the second type). The first type of inlet and nearshore sediments are more rich in carbonate minerals which may be attributed to carbonate materials derived by longshore current from external source or locally fragments of $\mathrm{Mg}$-Calcite in Composition.

The second type of the outlet sediments is characterized by higher content of gypsum and halite than the first type. This is may be due to the abundance of sabkhatized patches and salt marshes spatially distribute within the outlet intertidal flat. The carbonate minerals in the second type are mainly representing the carbonate skeletal of algae and other microfounal shells.

Chemical analysis of major elements in the form of oxides have been detected in the four representative samples, using $\mathrm{XRF}$, is given in Figure 14. This analysis has been applied in order to evaluate the chemical composition of the study sediments and its correlation with the bulk mineralogical composition (Table 6). The distribution of the major elements throughout the study sediments points to the following to observations.

1. The major elemental distribution may confirmed the mineralogical classification of the study sediments by XRD analysis (Figure 14) into first and second types, where the first type (inlet and nearshore sediments) are relatively richer in $\mathrm{CaO}, \mathrm{Al}_{2} \mathrm{O}_{3}$ and $\mathrm{Fe}_{2} \mathrm{O}_{3}$, while the second type (outlet sediments) are rich in $\mathrm{Na}_{2} \mathrm{O}, \mathrm{Cl}$ and $\mathrm{SO}_{3}$. These two major elements groups suggest the presence of carbonate, clay and iron oxide minerals in the first type in greater amounts than the second type which is rich in halite and gypsum. However, the iron oxide mineral (e.g. hematite) is not detected in the XRD chart (Figures 10 and 11) and this most probably, points to the presence of amorphous or gelatinous nature of iron oxide materials in the study sediments.

2. The chemical analysis reveals direct proportional between silica, $\mathrm{CaO}, \mathrm{MgO}, \mathrm{NaO}$ and $\mathrm{SO}_{3}$ in one side and calcite, dolomite, halite and gypsum in the other side respectively (Table 6).

The distribution of clay minerals in the clay size fractions which could be correlated with grain size classes, heavy metals distribution and other environmental parameters (such as total organic carbon, TOC, and brine; sodium chloride), is given in (Table 4). The identified clay minerals are kaolinite, illite, chlorite and irregular mixed layer illite / Smectite with dominant illitesmectite with dominant illite layers. Kaolinite and illite are present in all samples of inlet nearshore and 
outlet sites in the Al Subiya marginal marine area while chlorite and mixed layer clay minerals are present in all sediments except sample TS 22. The maxima of mixed layer clay minerals (46-38\%) were detected in samples NS 6 and TS 20 whereas the kaolinite dominates the nearshore sediments.

Table 4. Chemical composition as major oxides percent's of representative sediments samples in Al Subiya marine area.

\begin{tabular}{|c|c|c|c|c|c|c|c|c|c|}
\hline Samples No. & $\mathrm{SiO}_{2}$ & $\mathrm{CaO}$ & $\mathrm{Al}_{2} \mathrm{O}_{3}$ & MgO & $\mathrm{Fe}_{2} \mathrm{O}_{3}$ & $\mathrm{Na2O}$ & CI & $\mathrm{K}_{2} \mathrm{O}$ & $\mathrm{SO}_{3}$ \\
\hline NS 6 & 31.27 & 26.92 & 6.79 & 4.53 & 4.38 & 3.20 & 1.80 & 1.48 & 0.30 \\
\hline MS 11 & 31.61 & 27.94 & 6.94 & 5.10 & 4.42 & 2.70 & 1.70 & 1.42 & 0.53 \\
\hline TS 20 & 33.22 & 20.09 & 6.61 & 4.23 & 3.58 & 9.93 & 6.30 & 1.39 & 0.53 \\
\hline
\end{tabular}

It is apparent that the Al Subiya nearshore open marine area (Site M) has higher clay size fraction with higher concentration of Koalinite. This Kaolinite with the other detected clay minerals seems to be deterital clay that derived from external source area, mainly from shut Al-Arab fluvial origin. Those sediments are temporary accumulated near the eastern coasts and then westerly moved. Along the coasts by longshore currents. These currents are capable moving only the fine (clay and silt) materials including the clay minerals, to the Al Subiya marginal nearshore area. The inlet muddy sediments containing mixed layer clay minerals as dominant component were deposited under fluviomarine - tidal environment in Khur Al Subiya. In contrast the outlet sediments seem to be differ from those of the nearshore and inlet sediments, where the sediments seem to be developed from debris of different source. The sediments including traces of clay minerals (mainly of mixed layers clay minerals) were carried out by longshore drift or thrown up by tidal waves to form the mixed sandy intertidal flat.

Generally, the distribution of the clay minerals is one of compositional factor affecting in the distribution of the environmental parameters (e.g. heavy metals and TOC) of the bottom sediments. However, in the present study no direct relationship has been observed between the clay mineral types and their relative abundance, and the heavy metals distribution (Table 5). This may be due to the complication in the origin of the detected detrital clay minerals that derived from different source under different hydrodynamic environmental condition.

Table 5. Distribution of clay minerals in clay size fractions in correlation with concentration of environmental parameters (in nearly averages) in the $N$, $M$ \& T sites of Al Subiya plant.

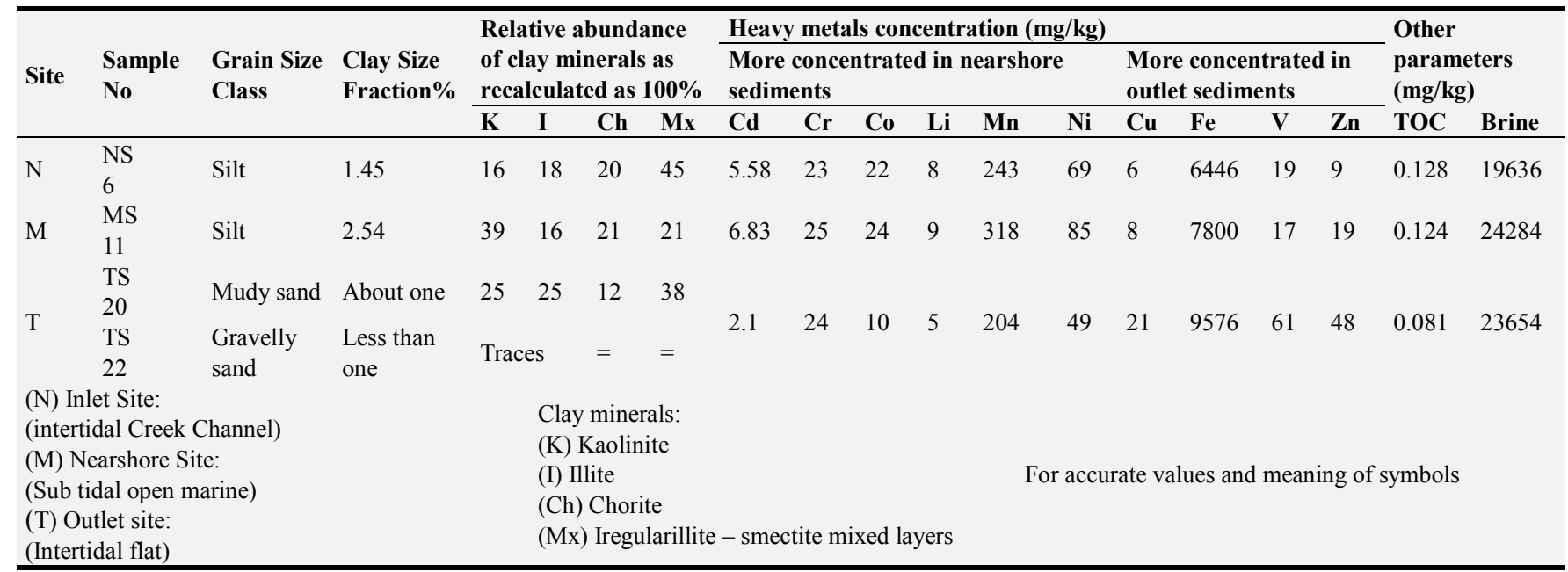

\subsection{Influence of Desalination Plant Technology}

One of most important factors is the technological condition that applied in discharging of the plant effluents and their treatment (blending) before their out falling into the nearshore (open marine) sea (i.e. site (M)). These technological conditions are likely to be affected in general by the design geometry and orientation of outlet site (i.e. site (T)) in which the salt incorporated with the intertidal flat mud, as well as salinity and temperature of the discharged brine and other procedures inside the plant-layout. Generally, the salinity of brine is directly dependent on the nature and salinity of the feed seawater at site $(\mathrm{N})$, where the salinity concentration of brine is twice the concentration of the natural seawater.

In all processes of desalination (like evaporation, multistage flash, MSF and reverse osmosis, RO processes) concentration discharged brines is higher than plants, like $\mathrm{Al}$ Subiya multistage Hash (MSF) technology, the discharge concentration seawater. Furthermore, the concentration of brines is influenced by initial feed (inlet) water quality and the plant process applied. Commonly, the brine discharged from physical, chemical and biological aspects compared to feed (inlet) water. It is generally characterized by multi component pollutants such as high concentration of salts and temperature as well as heavy metals. Other various chemicals 
used in the pretreatment stage of desalination, (e.g. various defouling materials) is included in some brines. However, type and amount of these chemicals used depend on the chosen technology and the required of the product water. Chemicals that are likely to be found in the brines include ant scaling materials surfactants and acids used for the lowering of $\mathrm{pH}$.

The Al Subiya plant is mostly based on evaporation processes and is combined with power station holds many advantages. The system includes services of compartments system, which contains sand filters, micron filters and a system for chemical dosing. The purpose of this pretreatment system is to protect the plant from by dirt.

To maximized mixing / dilution of brine that discharged from the Al Subiya plant before dissipation in the nearshore open sea of the discharging side (Figures 13 and 14). In this respect Al Subiya plant dilutes the concentrated brine with fresh seawater flushing blending so that the concentration discharged water be equal or close that of the seawater. The main environmental advantage of Al Subiya plant is the high dilution ration achieved where relatively low specific weight of the fresh seawater would partially offset the high specific weight of the brines and would therefore reduce their tendency to sink to the bottom.

On the other hand, rapid mixing, dilution and dispersion of the discharged effluent of Al Subiya plant are site dependent. The site of the outlet that adjacent to the discharge point is located to the southwest intertidal flat in the vicinity of $\mathrm{Al}$ Subiya plant. Several connected entrenched channels are artificially, designed as pass-way of the discharged effluents (mainly brine). These effluents follow sinuous courses of the channels before point to the sub tidal nearshore open sea. The temperature and salinity, which are slightly elevated at brine discharged sites (Site $(\mathrm{T})$ ), rapid further mixing and disaggregating through the entrenched channel, helps to minimize the effect in receiving water the outfall point. By this segregation after the flushing by fresh seawater the effluents almost come to the outfall point having a quality that closed to the seawater ambient condition. However, as a result of siltation and accumulation of dust in the channels by time, they need to be maintained by suitable mitigation measures.

\subsection{Potential Impacts}

Water desalination processes offer great benefits (e.g. fresh potable water supply) and at the same time cause several negative impacts on the marine environment. These impact on land use, ground water, marine environments and noise level as well as direct or indirect negative impacts of intensified use of energy were summarized by [1]. However, among these negative impacts, marine environment is the most important, marine environment is the most important item in the case of the Al Subiya desalination processes for the following reasons.

1. The Al Subiya plant is located at a suitable distance from population centers.

2. The aquifer is already externally saline within Ras Al
Subiya remote coastal area.

For these reasons the negative impacts on land use, ground water and noise pollution could be currently negligible, however, in the future may be considered. Therefore, the present section deals mainly with physical and chemical potential impacts on marine water and sediments in the vicinity of Al Subiya plant area. The effects of the discharged effluents containing brine and their distribution. The impacts of rising in temperature and increasing of salinity concentration of the effluents on the surrounding eco system will be reviewed based on the previous related studies. However, technological means may be employed in order to reduce or prevent almost these harmful impacts. Such similar technological means and other mitigation measures are currently other mitigation measures are currently carried out in Al Subiya plant as it will be discussed in this section.

\subsubsection{Physical and Chemical Quality of Seawater}

Physical and chemical impacts include effects of brine discharged, viz elevation in temperature, salinity and turbidity of seawater. As previously mentioned the main impact is due to the discharged of the concentrated brine to the sea and its magnitude depends on environmental and its hydro geological factors of the sea. These factors would determine the extent of the mixing and dilution of the brines and therefore the spatial range of the impact.

It was indicated in that the brine discharged from $\mathrm{Al}$ Subiya plant at the outlet (Site T) is higher concentration than that of the original sweater at the inlet (site N) while it ranges from 43 to $44 \mathrm{ppt}$ at site $(\mathrm{M})$.

Considering that the mean Kuwait water salinity in August is $41 \mathrm{ppt}$ [16]. The result indicated a potential impact by salinity between 1-2 ppt above mean salinity from the brine dissipated point of the outfall to the adjacent nearshore area of the Al Subiya plant. The increase in salinity (ranging from 43 to $44 \mathrm{ppt}$ ) above mean value is higher than the limit of marine water quality set by Kuwait Environment Public Authority (KEPA) from seawater quality but comparable to the standard limits in other countries.

In conclusion the seawater concentration in the area $(\mathrm{M})$ is slightly higher than ambient salinity concentration but within the permissible limits. In this specific case of Al Subiya plant there are no apparent threats due to salinity exceedance. This resultant conclusion is attributed to the following technological and hydrodynamic factors. The feed seawater concentration at $(\mathrm{N})$ is less than $42 \mathrm{ppt}$ and the brine concentration, after mixing and dilution by fresh seawater, at the discharged point a $(\mathrm{T})$ is about 53ppt in average giving ratio of 1.2. However, this brine does not discharge direct into the open sea, but it is accomplished using irregular entrenched channels occupying the tidal flat of the $\mathrm{T}$ site. The brine discharged from the plant being denser than receiving seawater, is reported to disperse in the sandy mud tidal flat ( $\mathrm{T}$ area) which is the immediate area. It rapidly sinks and trapped in the sinuous entrenched channels forming salt crust and sabkha sediments by evaporation. However, through its flow the relatively low specific weight of the hot 
water would partially offset the high specific weight of the brine.

At the seawater exit of the entrenched channels (at the dissipated point of the outfall) the brine attains additional dilution in the immediate area after discharge points. This treated brine which riches the open sea at (M) nearshore area, is carried away by the tide and marine currents allowing more rapid mixing and dilution immediately after out falling. Consequently, the salinity tends to return to ambient condition and spread over a large area where it is more or less similar to that in the open sea.

However, the increased salinity acts as a buffering agent for acidifying Gulf waters. The huge desalination capacity installed in the Gulf produces more than $33 \mathrm{MCM}$ of concentrated brine each day which is neutralized by the Arabian Gulfs acidifying waters. The bottom sediments of the Arabian Gulf are predominantly carbonates, which are quite sensitive to $\mathrm{pH}$ variations. The increase salinity and alkalinity measurements suggest that the buffering capacity of the Gulf's waters has increased, and the acidification has weakened. This is a positive side effect of the higher salinity. The dissolution of carbonate lags six months to a year from the $\mathrm{pH}$ drop. During which the coral communities are under immense stress. Some corals have been observed to resist this $\mathrm{pH}$ stress by allowing the growth of coralline algae over their hard substrate. The coralline algae well in acidifying water, which is believed to be $\mathrm{CO}_{2}$-rich. Thus, the long-term effect of desalination in the Arabian Gulf is not entirely negative; it is helping to counter the acidification by increasing the buffering capacity of the seawater and stabilizing the $\mathrm{pH}$.

The temperature of the brine discharge is one of the major concerns for any desalination plant where thermal impact can occur by resin seawater temperature, normally about $7-12^{\circ} \mathrm{C}$ or more above feed (inlet) seawater. Consequently, this elevation in temperature of receiving seawater results in alteration of the physical characteristics of the seawater and marine region around the plant.

In this case the brine with its high temperature is discharged directly to the sea through an outlet system without considerable treatment and that could have impacts on the bottom fauna around the location of marine out falling. But this is not the case in the Al Subiya plant where the brine is blended thoroughly with cold fresh seawater and exposed to the air temperature during its accomplishment in long sinuous entrenched channels (not less than $3 \mathrm{~km}$ length) of the outlet system.

The blended brine is then rapid mixing immediately after out falling that followed by dilution and diffusion caused by winds waves and tides and incursion of water masses was highly robust. Accordingly, the hydrodynamic condition may cause in temperature dispersion and decreasing trend from the Al Subiya outfall discharge point toward offshore. The temperature in such system will be reduced and return to the ambient temperature that prevailing during the season of sampling or slightly warmer than the feed water. Therefore, the thermal impact at vicinity of Al Subiya plant could be negligible or very slightly harmful on micro fauna.
The dissolved oxygen (DO) concentration depends upon not only on hydrodynamic marine environment but also upon seawater temperature. Dissolved Oxygen (DO) increases with high wave dynamic in open marine environment and decreases in enclosed quite marine bodies. Oxygen becomes less soluble in seawater with increase in temperature and salinity, so it is reduced in discharged outfall particularly in surface layer of water. However, it is indicated in the present study that the dissolved oxygen (DO) level at Al Subiya plant marine (The M Site) which occur in open and moderate to high current dynamics, is found quite normal, where it ranges from about 4.5 to $5.8 \mathrm{mg} / \mathrm{L}$.

In relation to availability of dissolved oxygen in the water, Rosalina oriental is tolerant to low dissolved oxygen (DO) in a seawater whereas is a tolerant to higher water temperature like that at south of Kuwait where Al-Zour plant located [7]. The open environment around this plant shows high wave dynamics and increase in the level of dissolved oxygen which result in high biodiversity (e.g. foraminifera species) exists, On the other hand, the semi-enclosed Kuwait bay in the northern end of Arabian Gulf, has limited water circulation and shows decreased level of DO which causes the reduction of foraminifera species along Al Subiya plant coast as compared with Al-Zour station [7].

In conclusion, water quality parameters including $\mathrm{DO}, \mathrm{pH}$ and conductivity at the study Al Subiya plant area are generally within Kuwait - EPA limits indicating relatively good quality of water.

\subsubsection{Bottom Sediments}

The distribution of common trace elements that get settled in the bottom sediments in the inlet, outlet and nearshore marginal marine area around the Al Subiya plant site. Trace metals such as Copper, Iron, Nickel and Zinc are possibly leached from heat exchangers and other components of thermal desalination plants [17]. These metals could be generated in the discharged brine as a result of the effect of seawater flow, dissolved gases and treatment chemicals on the alloys used in the desalination pipes and other equipment's [18]. Trace metals rejected in the brine may be present in dissolved from depending on their solubility properties and / or may remain suspended in the effluent and may get settled in the sediments. Sediments thus acts as sink to these metals and offers a better matrix for assessing the distribution and impacts of anthropogenic inputs in localized areas near industrial activities such as power and desalination plants than seawater [18].

The Positive correlation between some heavy trace metals, particularly $\mathrm{Cu}, \mathrm{Fe}, \mathrm{Cr}, \mathrm{Ni}, \mathrm{Co} \mathrm{Zn}$ and $\mathrm{V}$, in bottom sediments of Al Subiya marginal marine area. Infer their similar source input. Thus control of their source will minimize their negative impact on the marine environment. These metals seem to be irregularly spatial distributed in different environmental sites ( $\mathrm{N}, \mathrm{M}$ and $\mathrm{T}$ ). However, they show similar considerable concentration in sites $\mathrm{N}$ and $\mathrm{M}$, but the ranges do not imply pollution at these sites. On the other side, the immediate outfall (site $\mathrm{T}$ ) is relatively polluted area 
where it contains high concentration of $\mathrm{Cu}, \mathrm{Fe}, \mathrm{Ni}$ and $\mathrm{V}$ comparing with the other sites. These results imply that the accumulate of heavy metal in sediments is influenced by their grain sizes where the corser grains may be settled or trapped within the sabkha mud sand of the outlet tidal flat.

Comparison with other locations in the Arabian Gulf and Kuwait bay indicated that the nearshore marine vicinity of $\mathrm{Al}$ Subiya Plant has relatively lower concentration of the majority of heavy trace metals. Consequently, Al Subiya could be described within the limits of unpolluted area. Generally concentrations exceeding the backgrounds significantly are considered as environmental pollution even biological consequences cannot be proven [18]. [19] Stated that it is still not possible to set a standard up to which metal pollution is harmless and from which it is harmful. Thus continual monitoring and assessment of the accumulated trace metals and their load in the sediment would be necessary.

\subsubsection{Biological Composition}

[17] Studied the effect (impact) of thermal pollution on microfouna "Foraminifera" in Ras Al - Subiya Plant area and compared it with that present in Ras Al Zour station area. She discussed the availability of dissolved oxygen and its relation to biodiversity as well as the use of bio indicator for defines environmental conditions. Also, [18] studied the biological impact in term of comparative environmental conditions around Al Doha and Al Zour stations. Based essentially on these literatures and other previous studies [20 and 1] as well as the results of the present environmental profile setting, the following conclusions could be revealed.

1. It was defined the principal environmental factors which appear to be most strongly influence the species habitat.

2. High biodiversity exists and more foraminifera species have been identified with increasing in the level of (DO) within open environment in the south of Kuwait along the Arabian Gulf around the Al Zour station. In contrast, with decreased level of (DO) as result of semi enclosed and limited water circulation that prevailed in water circulation that prevailed in Kuwait Bay, the level of foraminifera species is retarded.

3. The distribution of different marine species diversity among different stations, including $\mathrm{Al}$ Doha and $\mathrm{Al}$ Zour stations, reflected environmental conditions (e.g temperature) salinity, light, etc.). For instance Al Doha area exhibited higher abundance and total number of species than Al Zour area, probably due to the large muddy nature of seabed compared at $\mathrm{Al}$ - Doha nature of seabed compared at Al Doha which encouraged macro faunal settlement.

4. Generally changes to salinity and temperature can play a significant role in the availability of dissolved oxygen in seawater and consequently in the growth and size of aquatic life and the marine species disturbance. However, several studies in the region suggest that though the salinity issue is serious but may not pose a serious danger to the biota and ecosystem health in particular in north Arabian Gulf, due to adaptability of higher temperatures and salinity in the region. But this adaptability is not applicable for many native species, where the increasing of salinity might be leading to extension of same and reduced biodiversity in general.

According to the Sensitivities of the global marine habitats to the effects of desalination plants, [20] Divided these habitats into 15 categories (Table 6). According to the hierarchy, which they suggest, the sites most suitable for the construction of desalination plants are the shores of the ocean (category No 1), in regions of high - energy oceanic coasts. The most sensitive regions are those of category No 15 of mangal (Mangrove flats). According to this categorization (Table 6), Al Subiya Plant site is less environmental sensitivity, than the other plants in Kuwait Bay. The Al Subiya marine region is relatively high energy soft tidal coast that could be rated at [5] while the others (southern and western plant sites) are shallow low energy bay which could be rated at 10 .

Table 6. Categorization of environmental Sensitivities of marine habitats to desalination plants [20].

\begin{tabular}{ll}
\hline Category rate & Definition \\
\hline 1 & High-Energy oceanic coasts, rocky or sandy, With \\
& coast-parallel current \\
2 & Exposed rocky coast \\
3 & Mature shoreline (sediment mobility) \\
4 & Coastal upwelling \\
5 & High-energy soft tidal coast \\
6 & Estuaries and estuary-similar \\
7 & Low energy sand-mud-and beach rocks-flats \\
8 & Coastal sabkhas \\
9 & Fjords \\
10 & Shallow low-energy bay and semi-enclosed lagoon \\
11 & Algal (cyanobacterial)mats \\
12 & Seaweed bay and shallows \\
13 & Coral reefs \\
14 & Salt marsh \\
15 & Mangal (mangrove flats) \\
\hline
\end{tabular}

\subsection{Management Measures}

Despite the high salinity values of the brine that discharged from Al Subiya Plant, these values are currently not posing any serious environmental concern. Furthermore, there is a room for further development and continuous keeping the advantages of Al Subiya plant. however, the concern become a more serious over time with decreasing fresh water input in Khor Al Subiya, possible drastic change in the regional oceanographic characteristics and finishing of the proposed urban project in Al Subiya region. Consequently, the environmental situation may turn adversely by time and then it needs further management measures for keeping Al Subiya and its long term development to be environmentally friendly plant.

Al Subiya like all the desalination plants in Kuwait, try to reduce the potential negative impacts of effluents including brine, leached chemicals and heavy metals, discharges and thus minimize their adverse effects on the receiving 
environment (e.g. site M). Therefore, it is very important to look into the efficiency of the currently processes of mixing and blending of brine with cold fresh seawater flushing to lower the salinity and temperature of brine before it is cascaded into the segregated zone (site T) [17] and finally to achieve zero elevation that closer to ambient seawater in the receiving marine environment. In this respect several alternative options might be explored for long term strategy, among of them are:

1. Mixing the brine products with some treated wastewater which may be disposed from the future new city in $\mathrm{Al}$ Subiya area. The option of using this water for dilution would be an advantage to the additional reprocessing of the brine.

2. Directing the brine to a salt production plant instead of returned it to the sea. This plant could be constructed in the vicinity of Al Subiya Plant. This option of utilization of brine (salt) products which should be carefully treated, may introduce environmental and economical advantages. However, it is preferable to use this treated salt for industrial purposes.

3. Discharging the final effluents after segregation in channels from outfall point (site $\mathrm{T}$ ) by a long pipe far into the off shore deeper marine environment. For better dispersion and dilution of discharge plume (if any) near the terminal point of this pipe. This option may help in further quick mixing and dispersion of the concentrated solutions by marine current and thus minimize their adverse effects on the ambient marine condition. It is worth to mention that the choice among this option may depend on the local incoming environmental conditions of the study Al Subiya area and its economic aspects.

4. To minimize the release of heavy metals resulting from corrosion of heat exchangers that come into contacts with seawater pre-treat the acidified seawater resulting from scale acid cleaning procedures through circulation on a limestone bed before discharge to the sea. This would before discharge to the sea. This would effectively increase the $\mathrm{pH}$ of the effluent.

5. Water and promote precipitation or adsorption of the heavy metals contamination before it mixes with seawater at the outfall.

6. For faster and maximum dilution, it is suggested to increase the numbers of outfall points at the ends of new entrenching channels in site $(\mathrm{T})$. For better disputation of out falling plumes (if any), diffuser system may be installed at the pints of submerged outfall termination. It is recommended to take the hydrodynamic characteristics and the biological underwater habitats conditions, into consideration before site selection of the suggested outfall points as well as before any further development of the existing plant.

7. Geoenvironmental field survey for the site $(\mathrm{T})$ of the subtidal flat including the outfall entrenched channels, should be carried out to evaluate the environmental profile of the site and monitoring the discharge rate of particulate matter that released from such outlet. it is evident that salt and sandy mud layer or crust incurred each year and accumulated in the channels and consequently reduce their depth and minimize the discharged effluent slow.

8. This situation become more serious over time where the channels are over flooded and the discharged brine flow directly to the open sea without segregation. Therefore to enhance the long term effectiveness of the entrenched channels, they need to be maintained, at least seasonally. Such maintenance may reduce the chance of over topping of the original channel banks.

9. These channels need scouring and dredging of their courses and bottoms to remove the excess trapped salty silt mud overfills so they return back to their initial shapes. The removed materials which may contain polluted elements and salts should be carefully transported inland and disposed into suitable dumping site or saved landfill site. Availability of such disposed sites is problematic in coastal area. Thus continual monitoring and assessment of the accumulated materials in the outlet site of Al Subiya area should be essential to prevent total pollution.

\section{Conclusion}

1. The nearshore bottom sediments $(\mathrm{M})$ which contain the highest amount of the clay size fractions and Kaolinite include the highest concentration of $\mathrm{Cd}, \mathrm{Cr}, \mathrm{Co}, \mathrm{Li}, \mathrm{Mn}$ and $\mathrm{Ni}$.

2. The outlet sediments $(\mathrm{T})$ which contain the low amount of the clay size fractions and the highest amount of mixed layer clay minerals (may be in the form of glauconitic materials), include the lowest concentration of $\mathrm{Cd}, \mathrm{Cr}, \mathrm{Co}, \mathrm{Li}, \mathrm{Mn}$ and $\mathrm{Ni}$ and at same time contain the highest concentration of $\mathrm{Cu}, \mathrm{Fe}, \mathrm{V}$ and $\mathrm{Zn}$. In the (T) sediments this study also identified negative correlation between clay minerals and both sand grain size content and presence of carbonate.

3. The inlet sediments $(\mathrm{N})$ which represent the fluviomarine intertidal creek channel environment contain more mixed layer clay minerals and intermediate concentrations of all types of the heavy metals (Table 5).

4. The observed categorized of the study heavy metals distribution (Table 5) may be attributed to differentiation in their particle size, nature of mobilization, capability of adsorption to the suspended clay particles and their response to the local hydrodynamic condition in the N, M and $\mathrm{T}$ sites of $\mathrm{Al}$ Subiya area. Consequently, the relatively more heavy metals of $\mathrm{Cu}, \mathrm{Fe}, \mathrm{V}$ and $\mathrm{Zn}$ are earlier precipitated and associated with the coarser sediments of the outlet $(\mathrm{T})$ site, while the other metals (e.g. Cd, Cr, Ce, $\mathrm{Li}, \mathrm{Mn}$ and $\mathrm{Ni}$ ) that adsorbed on the suspended clay particles and 
dispersed further away to the nearshore (M) site.

5. In this study, the concentration of the TOC shows more positively correlation with the percentage of clay size particles, than with types and relative abundance of clay minerals. Thus, finer particle size tends to be associated with organic matter. In agreement with [14 and 15], that the significant positive correlation between organic matter content and clay content is due to the large surface area of the clay particles and high capability of adsorption of these matter to these particle surfaces. On the other hand, the clay contents did not show any correlation with the brine concentration (Table 5).

\section{Acknowledgements}

The authors would like to thanks Cairo University, Dept. of Earth and Environmental Science, College of Science, Kuwait University and Kuwait University Environmental Lab. The Corresponding author would like to thanks Dept. of Earth and Environmental Science, Florida International University, USA.

\section{References}

[1] Enva Rachel, Harussi Kobiand and Perry Dan, (2002), The Footprint of the Desalination Processes, Desalination 152, 141-154.

[2] Talat Saeed, Khordagui Husny and Al-Hashash Huda, (1999 a), Contribution of Power/Desalination Plants to The Levels of Halogenated Volatile Liquid Hydrocarbons in The Coastal Areas of Kuwait, desalination, 121: 49-63.

[3] Talat Saeed, Khordagui Husny and Al-Bloushi Amal, (1999 b), Distribution of Volatile Liquid Hydrocarbons in The Vicinity of Power/Desalination Plants in Kuwait, wat.sci. tech, 40, 99-107.

[4] Al-Sarawi, M., Massoud, M. S., and Al-Abdali, F., (1998 a), Preliminary Assessment of Oil Contamination Levels in Soil Contaminated With Oil Lakes in Greater Burgan Oil Fields, Kuwait. Water, Air and Soil Pollution, 106: 493-504.

[5] Al-Sarawi, M., Massoud, M. S., and Wahba, S. A., (1998 b), Physical Properties As Indicators of Oil Penetration in Soils Contaminated with Oil Lakes in the Greater Burgan Oil Fields, Kuwait. Water, Air and Soil Pollution, 102: 115.

[6] Massoud, M. S., Al-Sarawi, M., and Wahba, S. A., (2000), Variations in The Chemical Properties of Soils Contaminated with Oil Lakes in The Greater Burgan Oil Fields, Kuwait. Water, Air and Soil pollution, 118: 281-297.
[7] Al Theyabi Noura (2012), Effect of Thermal Pollution on Microfauna "Foraminifera" A Case Study of Ras Al Zour And Ras Al Subiyd Power Stations, State of Kuwait, Unpublished Theses, Kuwait University 145 page.

[8] Al Hurban, A., El-Gamily, H. and El-Sammak, A. (2007), Geomorphic Changes in Ras Al Subiyah Area, Kuwait. Volume 54, Issue 7, pp 1377-1390.

[9] APHA, (2013), Standard methods for examination of water and wastewater, $22^{\text {nd }}$ Edition.

[10] Kuwait Environmental Protection Authority, (2002), May, Technical Report, 73 Pages.

[11] EPA, (1998), N-Hexane Extractable Material for Sludge, Sediment and Solid Samples, Method 9071B.

[12] Sahuquillo, A., Lopez-Sanchez, J. F., Rubio, R., Rauret, G., Thomas, R. P., Davidson, C. M., Ure, A. M., (1999). Use of a Certified Reference Material for Extractable Trace Metals to Assess Sources of Uncertainty in the BCR Three-stage Sequential Extraction Procedure. Anal. Chim. Acta 382, 317-327.

[13] Al Shemmari H., Al Dousari., A. M., Lina, T., and $\mathrm{Al}$ Ghadban, A. N., (2013), Mineralogical characteristics of surface sediment in Sulaibikhat Bay, Kuwait. Kuwait J. Sci. 40 (2) pp. 159-176.

[14] Keil, R. G., Fuh, E., Giddings, C. B., and Hedges, J. I., (1994), Mineralogical and Textural Controls on the Organic Composition of Coastal Marine Sediments: Hydrodynamic Separation Using SPLITT-Fraction. Geochemical Cosmochimica Acta 58: 897-893.

[15] Kim, Y., Kim, K., Kang, H. D., Kim, W., Doh, S. H., Kim, D. S. \& Kim, B. K., (2007), The Accumulation of Radiocesium in Coarse Marine Sediment: Effects of Minerology and Organic Content. Marine Pollution Bulletin 54: 1341-1350.

[16] Ghannoum, M. A., Al-Sarawi, M., ABO Alyan, A. and Baca, B. (1991). Microbiological Water Quality Along the Kuwait Waterfront Project, Kuwait. INTERN. J. Environmental studies, 37, 65- 71 .

[17] Shams El din A. M., Aziz Shawki and Makkawi B., (1994), Electricity and Water Production in the Emirate of Abu Dhabi and its Impact on the Environment, desalination, 97, 373-388.

[18] Ali, 1. N., Al-Dousari, A., and Talebi, L., (2009), Impact of Desalination Plants Discharge Effluent on the Marine Environment in Kuwait. KISR 9699

[19] Hopner, T., (1999), A procedure for Environmental Impact Aassessments (EIA) for Seawater Desalination Plants. Desalination, 124: 1-12.

[20] Hopner, T., and Windelberg, J., (1996), Elements of Environmental Impact Studies on the Coastal Desalination Plants, Desalination, 108: 11-18. 